\title{
REVISION OF THE DISJUNCT GENUS CAMPYLANTHUS (SCROPHULARIACEAE)
}

\author{
M. HJERTSON*
}

\begin{abstract}
The genus Campylanthus (Scrophulariaceae) is revised and 15 species are recognized. The genus shows a markedly disjunct pattern of distribution, with two species in Macaronesia, 12 in northeastern Africa and Arabia, and one in western Pakistan. With few exceptions all have very restricted distributions. The position of the genus within the Scrophulariaceae is discussed, and it is concluded that Campylanthus is best placed as incertae sedis. Morphological aspects of the genus are discussed and a cladistic analysis including all species is presented. The analysis indicates a basal split between western and eastern species in the genus. A key, descriptions and distribution maps for all species are provided, and some lectotypes and neotypes are selected.
\end{abstract}

Keywords. Biogeography, Campylanthus, disjunction, generic position, morphology, phylogeny, revision, Scrophulariaceae, taxonomy.

\section{INTRODUCTION}

Campylanthus Roth is a small genus of shrubs and subshrubs. It shows a markedly disjunct pattern of distribution, with two species in Macaronesia, 12 in northeastern Africa and Arabia, and one in western Pakistan.

The circumscription of the genus has remained stable since it was separated from Eranthemum L. (Acanthaceae) by Roth (1821). Bentham (1846) recognized two species, whereas nine were recognized in the latest complete treatment of the genus (Miller, 1980). Since 1980, four additional species and one variety have been described.

The position of Campylanthus within the Scrophulariaceae is enigmatic. In the system of Bentham \& Hooker (1886) it was placed in the tribe Digitaleae of subfamily Rhinanthoideae. This treatment was also followed by Wettstein (1891), who made the latest complete treatment of the Scrophulariaceae. However, there are no obvious relatives of Campylanthus in Digitaleae and the proper position of the genus remains uncertain.

The present study aims at a revision of all known species of Campylanthus and an improved understanding of its morphology, phylogeny, biogeography, and position within Scrophulariaceae.

\section{HISTORICAL OUTLINE}

The first species of Campylanthus was discovered by Francis Masson on Tenerife in the Canary Islands in 1778, and described by Linnaeus f. (1782) as Eranthemum salsoloides $[=$ Campylanthus salsoloides (L.f.) Roth].

\footnotetext{
* Museum of Evolution, Botany Section, Uppsala University, Norbyvägen 16, SE-752 36 Uppsala,
} Sweden. E-mail: mats.hjertson@evolmuseum.uu.se 
The genus Campylanthus was described by Roth (1821) who realized that Eranthemum salsoloides differed from all the other species of Eranthemum known to him. Roth's generic description is very exact, and he even listed six characters pointing out the differences between Campylanthus and Eranthemum.

Three additional species of Campylanthus were described between 1846 and 1849 (Bentham, 1846; Edgeworth, 1847; Wight, 1849). Among these, C. junceus Edgew. from Aden was the first in the genus to be described from the Afro-Arabian region.

A fifth species, C. spinosus Balf.f., was discovered by Balfour, Cockburn and Scott during their expedition to Socotra in 1880 .

In 1929, the genus Chamaecanthus Chiov. with the single species C. pumilus Chiov. was described, based on material from northeastern Somalia (Chiovenda, 1929). However, this is simply a redescription of Campylanthus spinosus (Miller, 1982). Interestingly, Chiovenda placed his new genus in the Acanthaceae, where Eranthemum in the present sense also belongs.

The first comprehensive treatment of Campylanthus was published by Miller (1980). He recognized nine species, of which four were described as new, C. incanus A.G. Mill. from Somalia, C. yemenensis A.G. Mill. from Yemen, and C. chascaniflorus A.G. Mill. and C. sedoides A.G. Mill. from Oman. The plants occurring on the Canary Islands and Cape Verde Islands were treated as a single, variable species under the name $C$. salsoloides (L.f.) Roth.

Since then four additional species have been described: C. somaliensis A.G. Mill. and C. mirandae A.G. Mill. from Somalia and Oman, respectively (Miller, 1988), C. antonii Thulin from the Mahra region in Yemen (Thulin, 1995) and C. parviflorus Hjertson \& A.G. Mill. from Somalia (Hjertson \& Miller, 2000).

\section{The position of CAMPYLANTHUS Within the SCROPHULARIACEAE}

The first attempt to place Campylanthus in a system was made by Reichenbach (1828), who regarded it as a member of the tribe Selagineae together with, for example, Globularia L., Selago L. and Agathelpis Choisy. The Selagineae, in turn, were included in the Acanthaceae together with the tribes Buchnereae and Acantheae. The Buchnereae (sensu Reichenbach) also included genera such as Erinus L. and Manulea L.

Lindley (1836) published a list provided by Bentham, in which Campylanthus was placed in the tribe Veroniceae of the Scrophulariaceae. It was also placed in Veroniceae by Endlicher (1839).

Webb (1845) described the monotypic subtribe Campylanthinae (as "Campylantheae") of the tribe Salpiglossideae, which was at that time included in the Scrophulariaceae (Bentham, 1835, 1846). In his first account Webb did not indicate whether this was a subtribe or a tribe, but later the same year the rank was explicitly stated to be that of subtribe (Webb \& Berthelot, 1845). It was subsequently raised to tribal rank in Spicilegia Gorgonea (Webb, 1849). Bentham (1846) placed Campylanthus together with Hydrotriche Zucc. initially in the tribe Gerardieae, noting 
that both were anomalous. Hydrotriche is considered to belong to the tribe Gratioleae (Bentham \& Hooker, 1886; Wettstein, 1891).

In Genera plantarum (Bentham \& Hooker, 1886) Campylanthus was finally placed in the tribe Digitaleae, following Erinus, with a note that it was without any close affinities, but seemed much better placed in the Digitaleae than in the Gerardieae. Wettstein (1891) also placed Campylanthus in the tribe Digitaleae, but between Calorhabdos Benth. and Oreosolen Hook.f., instead of close to Erinus.

Hallier (1903) discussed the position of Campylanthus in more detail. He admitted that it was so different from other members of the Digitaleae that he had considered removing it from that tribe. He stated that judged by habit, inflorescence and flower morphology one could almost take it for a member of the tribe Manuleae. However, as there are differences in anther morphology between Campylanthus and the Manuleae, and as it resembles the genus Wulfenia Jacq. in the shape of the corolla, the two stamens, and the shape of the capsule, he concluded that it should remain in the Digitaleae. Concerning the seeds in Campylanthus, he noted that winged seeds of similar type also occur in Alectorolophus Zinn [= Rhinanthus L.], Linaria Mill., Veronica L. and Aragoa Kunth.

Thieret (1967) discussed Wettstein's (1891) arrangement of the Scrophulariaceae, and a number of tribes were discussed in more detail, with special emphasis on difficult taxa. However, Thieret did not add any new comments regarding the position of Campylanthus.

Kooiman (1970) investigated the occurrence of iridoid glycosides in the Scrophulariaceae, and found that members of the tribe Digitaleae are devoid of aucubin, except for Erinus and Rehmannia Libosch. ex Fisch. \& C.A. Mey. Campylanthus, which also contains aucubin, was placed in the tribe Veroniceae, where most members were found to contain this substance. However, the presence of aucubin is widespread in the Scrophulariaceae and can be found in most tribes. Notable exceptions are the tribes Calceolarieae and Antirrhineae. A subsequent paper on iridoid glycosides (Hegnauer \& Kooiman, 1978) basically confirmed the earlier results of Kooiman (1970), with the exception that Erinus was transferred to the tribe Veroniceae.

Licht (1983), in a series of papers discussing the development of the root system in the Veroniceae, also investigated Campylanthus. The root system in Campylanthus consists of a primary root with a variable number of lateral roots emerging from it. $\mathrm{He}$ also commented on the orange-red colour of the root, which is caused by a substance in the vacuole of the exodermis, according to an unpublished thesis by Albert (1976). Orange roots are also known to occur in Craterostigma Hochst. of the tribe Gratioleae (Fischer, 1992), but here the coloured substance is found in the intracellular spaces and not in the vacuole. According to Licht's investigation, the root system, including the orange-red colour, and the seedling in Campylanthus are completely different from other members of the Veroniceae, and he doubted the placement of Campylanthus in this tribe.

Bigazzi (1993), in a study of intranuclear inclusions in the Scrophulariaceae, 
reported lamellar inclusions in Campylanthus as opposed to the amorphous inclusions found in other Veroniceae (including Erinus). According to Bigazzi Campylanthus should be removed from the tribe Veroniceae to a tribe where lamellar inclusions are present, i.e. Gratioleae, Verbasceae, Scrophularieae, Manuleae, Calceolarieae, Hemimerideae, Rhinantheae, or Gerardieae, but he did not make any more precise suggestion on where to place it. The Verbasceae are polymorphic with regard to the presence of lamellar inclusions, as most taxa lack them or have amorphous inclusions. The presence of lamellar inclusions in the Digitaleae is restricted to Rehmannia, a genus which also has a different alkaloid content from Digitalis and Isoplexis (Kooiman, 1970; Hegnauer \& Kooiman, 1978).

Miller (1980), in his revision of the genus, stated that the inclusion of Campylanthus in the heterogeneous tribe Digitaleae does not shed any light on the affinities of the genus, and that it remains an anomaly without any apparent close relatives in the family.

Molecular studies on the Scrophulariaceae have been performed by, for example, Olmstead \& Reeves (1995), and when more taxa are added to the analyses, the patterns will hopefully get clearer. Molecular phylogenies may be very useful for the re-interpretation of characters, or simply for widening our minds that might have been too biased towards old classifications. In the case of Scrophulariaceae, I am convinced that future studies will lead to a complete re-evaluation of the family, at both tribal and family level, as the results of Olmstead \& Reeves (1995) already imply. Results from an analysis of $n d h \mathrm{~F}$ sequences of Campylanthus and a limited sample of other members of Scrophulariaceae and related families indicate a position for Campylanthus near Digitalis (Hjertson, 1997). The proper position is likely to be solved only when further DNA analyses with a much wider sampling have been made. As a consequence, I now consider Campylanthus as best placed in the Scrophulariaceae as incertae sedis, pending further research.

\section{MORPHOLOGY}

\section{Habit}

Most species of Campylanthus are shrubs or dwarf shrubs, with more or less obvious xerophytic adaptations. These adaptations, as well as other characters, are discussed below.

\section{Stems}

Spine-tipped stems are a feature found, to various degrees, in C. anisotrichus (A.G. Mill.) Hjertson \& A.G. Mill., C. incanus, C. mirandae, C. parviflorus, C. pungens, C. ramosissimus Wight, C. spinosus Balf.f. and C. yemenensis. The spines are most distinctly developed in C. spinosus, where they show no leaf traces, whereas in the other species, leaf traces can be found almost to the tips of the spines.

In some species, notably $C$. antonii, $C$. junceus, $C$. pungens, $C$. ramosissimus and 
C. yemenensis, the stomata of the stems are distinctly sunken. The depressions may be shallow to deep, and the surface of the depression is covered by a granular layer that most likely consists of wax. This character is best developed in C. pungens (Fig. 1), where it can be seen at very low magnification. It appears that the stems play an important role in the photosynthesis of these taxa, and the leaves are usually few and very small.

\section{Indumentum}

The indumentum of the stems and leaves usually consists of eglandular, more or less erect, uniseriate hairs, which can be long and narrow to short and thick. A very different indumentum is found in C. anisotrichus, C. incanus, C. parviflorus and $C$. spinosus, which have appressed parallel hairs. In $C$. anisotrichus, $C$. incanus and $C$. parviflorus the hairs bifurcate, with two arms of equal length in $C$. incanus, and with one arm distinctly shorter in C. anisotrichus and C. parviflorus (Hjertson \& Miller, 2000). Hairs with a distinctly swollen base are found in C. antonii, C. junceus, $C$. pungens, C. ramosissimus and C. yemenensis, a feature not found in other species of Campylanthus. One species, C. somaliensis, has an indumentum consisting of glandular hairs.

The outer surface of the corolla is usually completely glabrous, but in C. salsoloides, C. sedoides and C. yemenensis it is hairy. The indumentum on the inner surface of the corolla tube consists of antrorse, unicellular hairs above the insertion of the stamens and retrorse, unicellular hairs below the insertion of the stamens. Hairs below the insertion of the stamens are absent in $C$. anisotrichus, $C$. incanus, $C$. parviflorus and C. spinosus.

The hairs on the inside of the calyx are glandular, a condition known in other genera of the Scrophulariaceae, for example Camptoloma Benth. (Hilliard, 1994) and Lindenbergia Lehm. pro parte (Hjertson, 1997). The outer surface of the calyx may be hairy or glabrous, but there are always at least some hairs on the margins of the calyx lobes.

\section{Flowers}

The flowers are arranged in terminal racemes that can be few- or many-flowered. The flowers are very shortly to distinctly pedicellate and are subtended by a bract and two basal bracteoles.

$$
\text { Calyx }
$$

The calyx is always 5-lobed with free lobes. This condition is common throughout the Scrophulariaceae and is found, for example, in Erinus (Hartl, 1974), Stemodia L. (Minod, 1918) and Verbascum L. (Hartl, 1974), and in many taxa of the tribes Antirrhineae (Sutton, 1988) and Manuleae (Hilliard, 1994). 

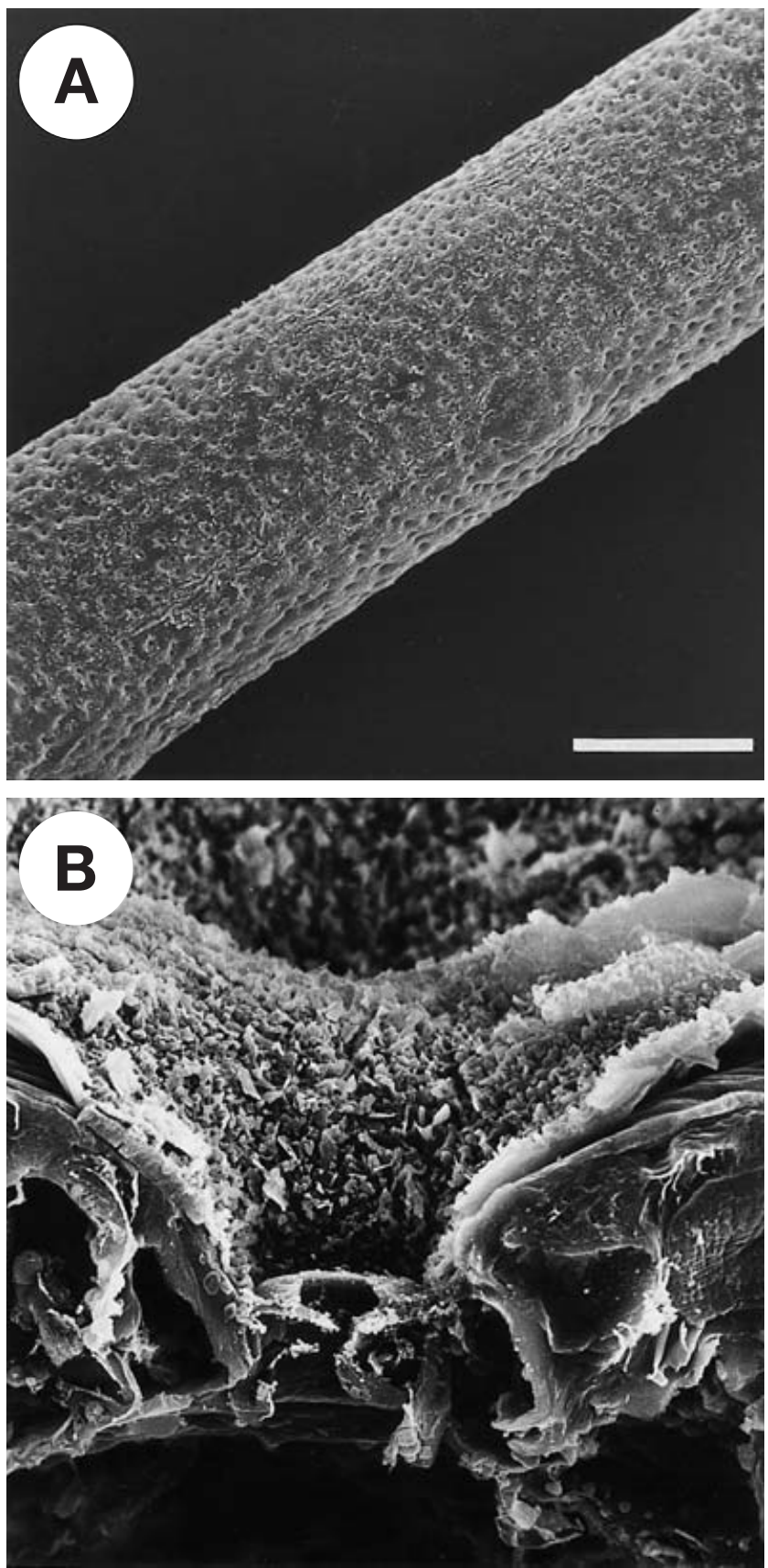

FIG. 1. SEM micrographs of sunken stomata in Campylanthus pungens (Podzorski 1188, E). Scale bar applies to A \& B. A. Stem; bar $=0.5 \mathrm{~mm}$. B. Cross-section of stoma; bar $=12 \mu \mathrm{m}$. 


\section{Corolla}

The corolla is more or less actinomorphic with a conspicuous cylindrical tube having two geniculations where the stamens are inserted. This is one of the diagnostic characters of the genus. Geniculated corolla tubes are also known in, for example, Jamesbrittenia Kuntze, Lyperia Benth. and Manulea L. of the tribe Manuleae (Hilliard, 1994). The colour varies from white to purple and in, for example, $C$. incanus and $C$. junceus, the throat is distinctly yellow. A peculiar flower colour is found in C. antonii, C. chascaniflorus and C. sedoides, in which the flowers are pinkish-brown to brownish.

No obvious pollinators were observed during the field work in Yemen and no reports of pollinators have been found in the literature. However, the generally longtubed flowers with a regular limb strongly suggest butterflies as pollinators (cf. Hilliard, 1994: 56). There is no indication that the flowers of any species are nocturnal.

\section{Androecium}

The two, very short stamens are free from each other and included in the corolla. They are borne on the corolla tube at the upper geniculation. There are no staminodes present. The anther thecae are divaricate and completely fused with a slight, central constriction.

\section{Pollen}

Two species were investigated, C. salsoloides (L.f.) Roth and C. spinosus. The pollen grains are tricolporate, prolate in shape, with a $20-23 \mu \mathrm{m}$ long polar axis and an equatorial diameter of $13-14 \mu \mathrm{m}$, and the surface is reticulate (Fig. 2). Only minor differences were observed between the two species. This pollen type is one of the two most common types within the Scrophulariaceae (Minkin \& Esbaugh, 1989), and it has been observed in, for example, Lindenbergia (Hjertson, 1996), Antirrhinum L. in the Antirrhineae (Elisens, 1986), Zaluzianskya F.W. Schmidt in the Manuleae (Argue, 1993), and Digitalis L. in the Digitaleae (Minkin \& Esbaugh, 1989).

\section{Gynoecium}

The ovary is ovoid, more or less laterally compressed, and glabrous. The style is filiform and the transition from the ovary to the style may be abrupt or gradual. The stigma is capitate and oblique, and is positioned at or slightly below the anthers. In a few species, $C$. chascaniflorus, $C$. sedoides and $C$. somaliensis, the sterile, apical part of the style is distinctly bifid, whereas it is entire in all other species. The capsules are ovoid to orbicular, distinctly compressed, and dehisce septicidally. 

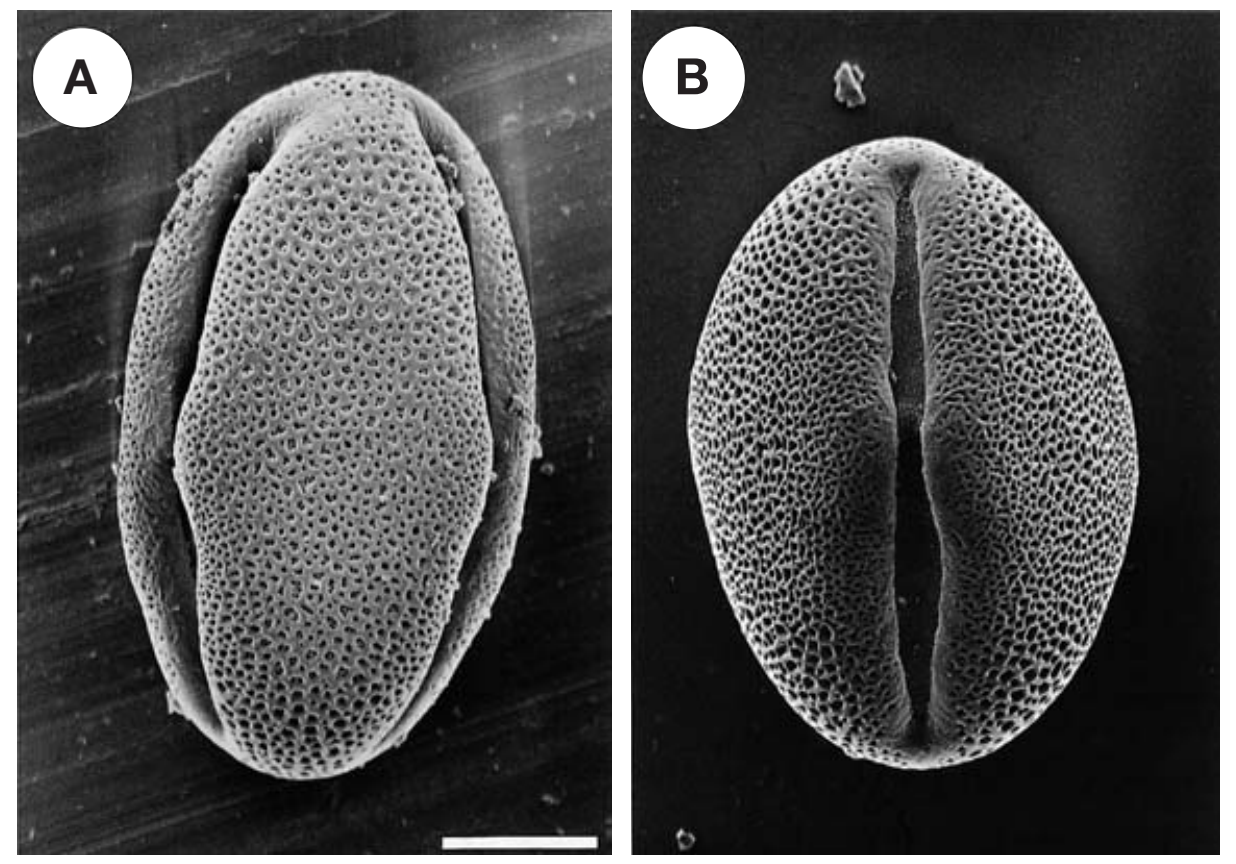

FIG. 2. SEM micrographs of Campylanthus pollen. Scale bar $=5 \mu \mathrm{m}$ and applies to A \& B. A. C. salsoloides (Davies 67328, E). B. C. spinosus (Smith \& Lavranos 366, K).

\section{Seeds}

The seeds are discoid in shape and around $1 \mathrm{~mm}$ in diameter, excluding the commonly present, more or less hyaline wing around the margin. In some species the wing is restricted to the funicular region only (Fig. 3).

\section{Chromosome numbers}

Chromosome counts of C. glaber (Bramwell \& Murray, 1972; Gomes et al., 1995) and of C. salsoloides (Larsen, 1960; Borgen, 1970) have been published, where $2 n=$ 14 was found. None of the Afro-Arabian species has been investigated cytologically.

\section{Cladistic analysis}

\section{Sampling and outgroup selection}

The characters used are shown in Table 1, and a data matrix of the characters is given in Table 2. In this analysis Agathelpis angustifolia Choisy, Anticharis glandulosa Aschers., Camptoloma lyperiiflorum (Vatke) Hilliard, Jamesbrittenia maxii (Hiern) Hilliard, Erinus alpinus L. and Freylinia tropica S. Moore were used as outgroups. Since there are no obvious close relatives of Campylanthus, an approach with several, 

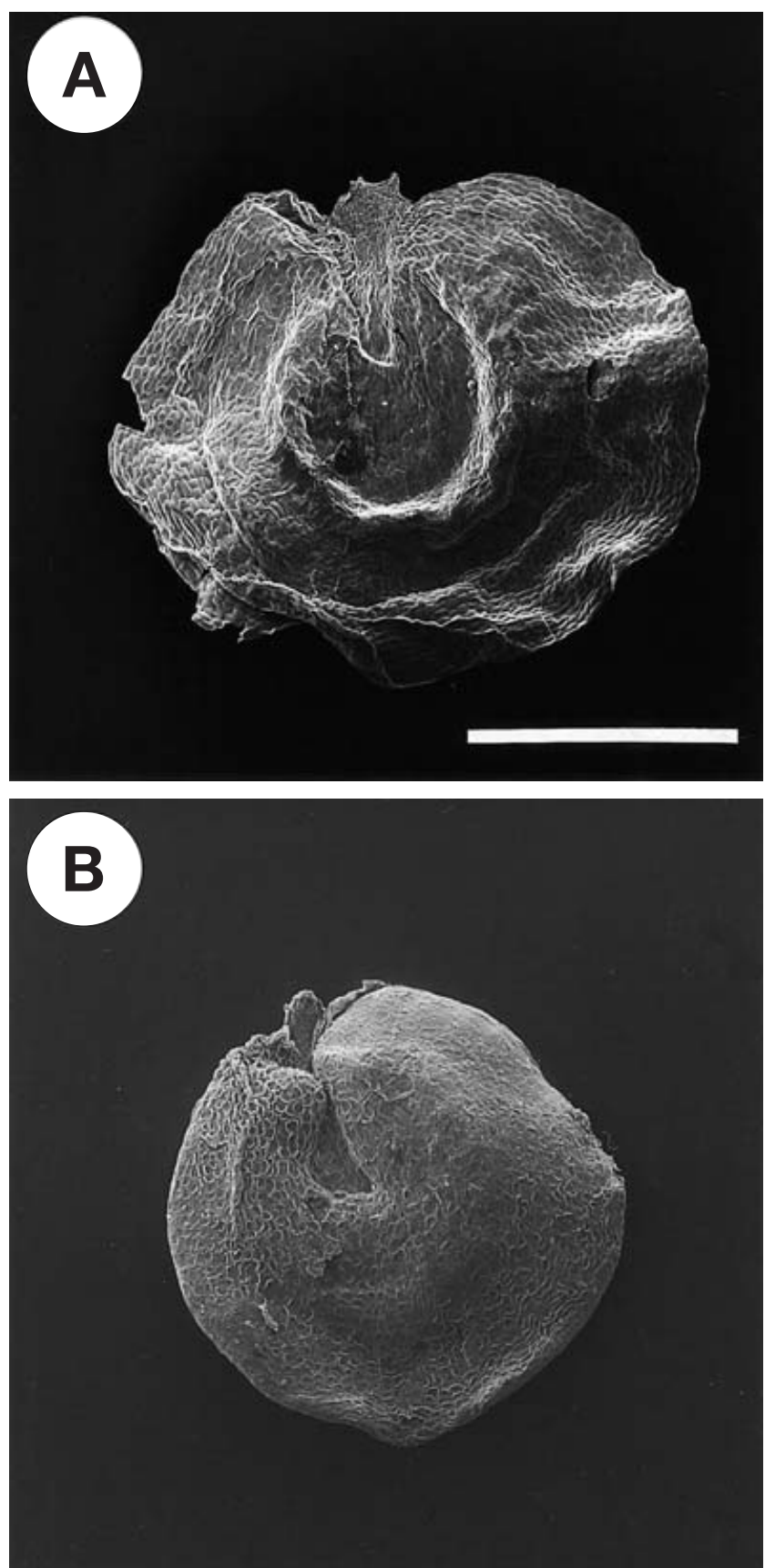

FIG. 3. SEM micrographs of Campylanthus seeds. Scale bar $=1 \mathrm{~mm}$ and applies to A \& B. A. C. pungens (Miller \& Nyberg 9202, E). B. C. somaliensis (Thulin \& Warfa 5560, UPS). Note that hyaline wing appears opaque in SEM micrographs. 
TABLE 1. Characters and character states used in the cladistic analysis of Campylanthus

1. Plants somewhat branched or branched from below only (0); much branched (1).

2. Branches not spinescent (0); spinescent (1).

3. Sunken stomata on stems absent (0); present (1).

4. Leaves opposite (0); alternate (1).

5. Persistent leaf bases absent (0); present (1).

6. Leaves serrate to dentate (0); entire (1).

7. Glandular hairs on vegetative parts absent (0); present (1).

8. Bifurcating hairs absent (0); present, isotrichous (1); present, anisotrichous (2).

9. Hairs on vegetative parts erect (0); appressed and parallel (1).

10. Base of hairs not swollen (0); swollen (1).

11. Inflorescence frondose (0); bracteate (1).

12. Inflorescence more than 5-flowered (0); up to 3-flowered (1).

13. Bracteoles absent (0); present (1).

14. Calyx without glandular hairs inside (0); with glandular hairs inside (1).

15. Calyx lobes hairy outside and on margins (0); hairy on margins only (1); glabrous (2).

16. Corolla outside glabrous (0); pilose (1).

17. Petal venation reticulate $(0)$; dichotomous (1).

18. Corolla tube $\leqslant 10 \mathrm{~mm}$ long $(0) ; \geqslant 11 \mathrm{~mm}$ long (1).

19. Corolla tube hairy below insertion of stamens (0); glabrous (1).

20. Geniculation at insertion of stamens absent (0); present (1).

21. Position of geniculation inside calyx (0); outside calyx (1).

22. Stamens four (0); two (1).

23. Anther thecae confluent with a \pm distinct central constriction (0); monothecous (1).

24. Anther thecae parallel (0); divaricate (1).

25. Ovary/style transition gradual (0); abrupt (1).

26. Apical, sterile part of style entire (0); bifid (1).

27. Stigma non-oblique (0); oblique (1).

28. Capsule with septicidal dehiscence (0); loculicidal and septicidal dehiscence (1); indehiscent (2).

29. Capsule not laterally compressed (0); laterally compressed (1).

30. Seeds oblong-elliptic, not winged (0); discoid with entire wing (1); discoid with wing restricted to the funicular region (2).

not necessarily closely related, outgroup taxa has been preferred. The rationale for using single species as representatives of the genera is to avoid variable states as far as possible.

\section{Methods}

A maximum parsimony analysis, using all species of Campylanthus, was performed using PAUP 3.1.1 (Swofford, 1993). Heuristic search options included: 1000 random addition replicates and tree-bisection-reconnection (TBR) branch swapping, saving all equally parsimonious trees, with all characters equally weighted and unordered (Fitch parsimony; Fitch, 1971). Characters were optimized using ACCTRAN. Clade stability was estimated using Bremer (Bremer, 1988, 1994) and bootstrap support 
TABLE 2. Data matrix assembled using the characters in Table 1 for the outgroup and Campylanthus. Polymorphic or variable taxa in characters with more than two states are coded with letters in the matrix: $a=0 / 1$, and inapplicable states are coded as ' $i$ '

\begin{tabular}{|c|c|c|c|c|c|c|}
\hline \multirow[b]{2}{*}{ Taxon } & \multicolumn{6}{|c|}{ Character number } \\
\hline & 12345 & $\begin{array}{r}1 \\
67890\end{array}$ & $\begin{array}{l}11111 \\
12345\end{array}$ & $\begin{array}{l}11112 \\
67890\end{array}$ & $\begin{array}{l}22222 \\
12345\end{array}$ & $\begin{array}{l}22223 \\
67890\end{array}$ \\
\hline Agathelpis angustifolia & 00011 & 10000 & 00002 & 00010 & i 1010 & 00200 \\
\hline Anticharis glandulosa & 00010 & 11000 & 00100 & 00010 & i 1000 & 00100 \\
\hline Camptoloma lyperiiflorum & 00010 & 01000 & 00010 & 00110 & i01 i0 & 00000 \\
\hline Erinus alpinus & 00010 & 00000 & 10000 & 10010 & i0001 & 00100 \\
\hline Freylinia tropica & 00001 & 00000 & 10001 & 00010 & i0000 & 00101 \\
\hline Jamesbrittenia maxii & 00000 & 01000 & 00000 & 00111 & i01 i0 & 00000 \\
\hline Campylanthus anisotrichus & 11010 & 10210 & 01110 & 01011 & 01011 & 01012 \\
\hline Campylanthus antonii & 00110 & 10001 & 00111 & 01101 & 11010 & 01012 \\
\hline Campylanthus chascaniflorus & 00010 & 10000 & 00110 & 01101 & 11011 & 11011 \\
\hline Campylanthus glaber & 00011 & 10000 & $1011 \mathrm{a}$ & 01001 & 11011 & 01011 \\
\hline Campylanthus incanus & 11010 & 10110 & 01110 & 01011 & 01011 & 01012 \\
\hline Campylanthus junceus & 00110 & 10001 & 00111 & 01001 & 11011 & 01011 \\
\hline Campylanthus mirandae & 11110 & 10001 & 00110 & 01001 & 01011 & 01011 \\
\hline Campylanthus parviflorus & 11010 & 10210 & 01110 & 01011 & 01011 & 01012 \\
\hline Campylanthus pungens & 11110 & 10001 & 00111 & 01001 & 11011 & 01011 \\
\hline Campylanthus ramosissimus & 11110 & 10001 & 00111 & 01001 & 01011 & 01011 \\
\hline Campylanthus salsoloides & 00011 & 10000 & 10110 & 11001 & 11011 & 01011 \\
\hline Campylanthus sedoides & 00011 & 10000 & 01110 & 11001 & 01011 & 11011 \\
\hline Campylanthus somaliensis & 00110 & 11000 & 00110 & 01101 & 11010 & 11012 \\
\hline Campylanthus spinosus & 11010 & 10010 & 01110 & 01011 & 01011 & 01012 \\
\hline Campylanthus yemenensis & 11110 & 10001 & 01110 & 11001 & 01010 & 01012 \\
\hline
\end{tabular}

values (Felsenstein, 1985). Bremer support values were calculated using topological constraints in PAUP. Bootstrap was calculated using 30,000 replicates, each with a single, random additional sequence of the taxa and nearest-neighbour-interchanges (NNI) branch swapping saving a single tree. The mapping of characters onto one of the equally parsimonious trees was done using the 'show reconstructions' option in PAUP.

\section{Results}

The analysis yielded three equally parsimonious trees, with a length of 64 steps, a retention index of 0.76 and a consistency index of 0.53 . The strict consensus tree is presented in Fig. 4, and one of the equally parsimonious trees is presented in Fig. 5.

The results show that the monophyly of Campylanthus with its current circumscription is well supported (96\% bootstrap value). An unresolved but well-supported clade (90\% bootstrap value) consisting of C. spinosus, C. incanus, C. anisotrichus 


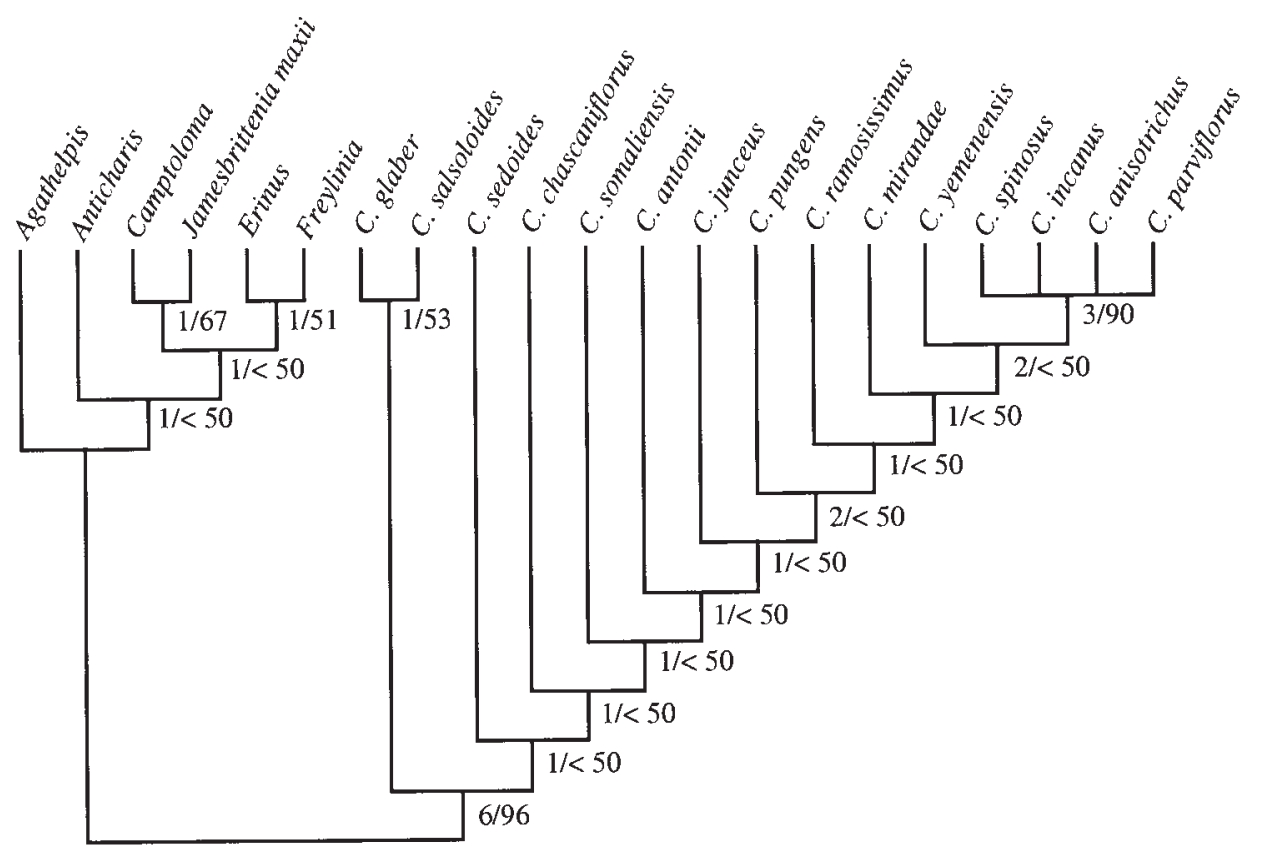

FIG. 4. Strict consensus tree of three most parsimonious trees resulting from the analysis of the morphological data in Table 1. Decay indices followed by bootstrap values are given to the right of each node.

and C. parviflorus is found at the top of the tree. The support values for all other nodes in the tree are low, including the basal branch (53\% bootstrap value) with $C$. glaber and C. salsoloides.

The Campylanthus clade is supported by nine characters, three of which are not homoplastic: the dichotomous corolla lobe venation (character 17), the oblique stigmas (character 27) and the laterally compressed capsules (character 29). The clade consisting of C. glaber and C. salsoloides is supported by character 11 (distinctly bracteate racemes), which also occurs as a parallelism in Erinus and Freylinia. The clade containing C. spinosus, C. incanus, C. anisotrichus and C. parviflorus is supported by three reversals: sunken stomata absent (character 3 ), base of hairs not swollen (character 10), and corolla tube glabrous below insertion of stamens (character 19); and a unique synapomorphy: indumentum of vegetative parts consisting of parallel, appressed hairs (character 9). For additional notes on characters, see discussion under 'Morphology' above.

\section{Discussion}

Since all taxa inhabit dry regions, water economy is obviously a problem. Two different means of reducing evaporation have developed in Campylanthus. Sunken 


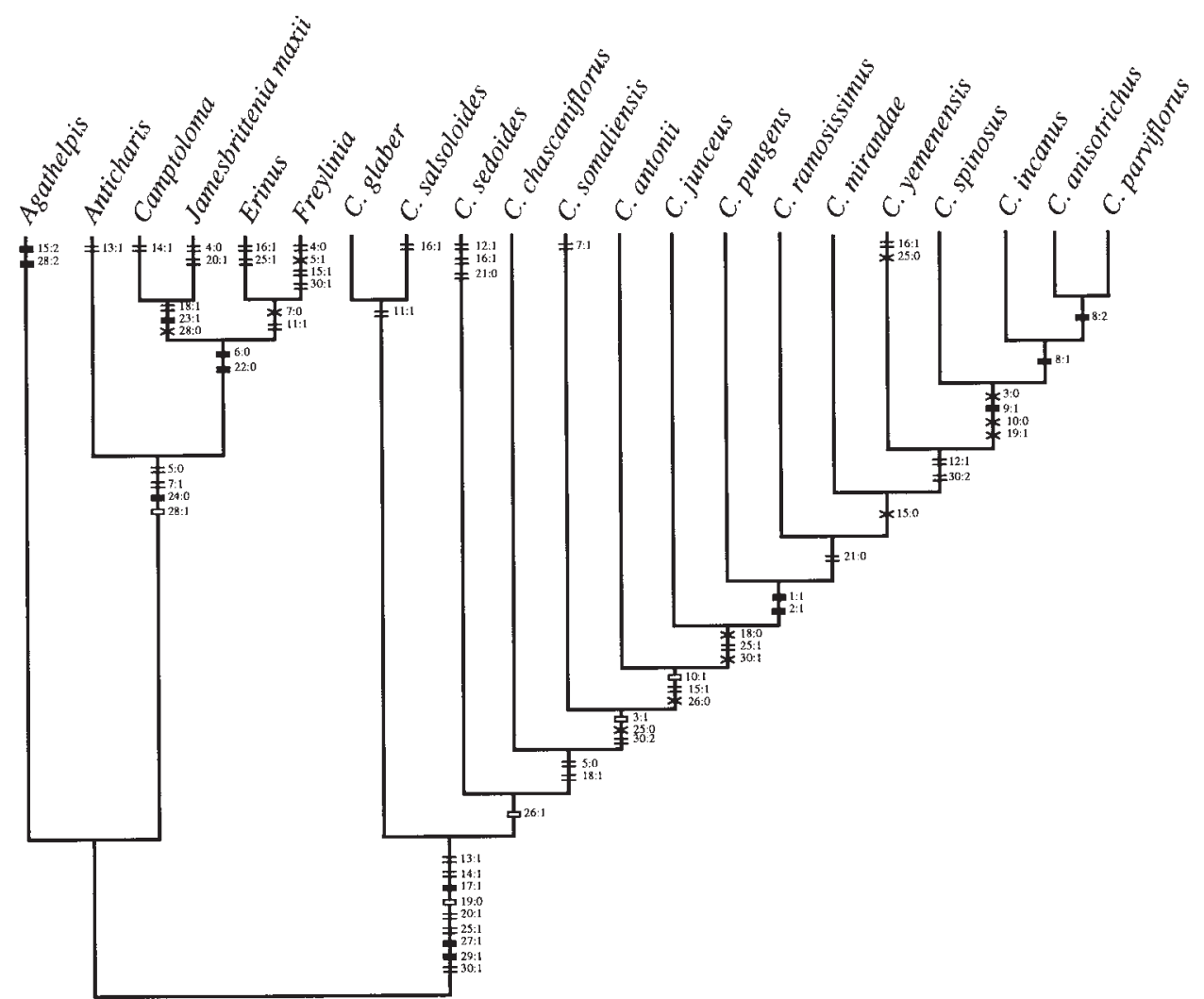

FIG. 5. One of three equally parsimonious trees from the cladistic analysis of Campylanthus with the characters optimized on the branches using ACCTRAN optimization. Black boxes indicate unique changes. Homoplasies are given as open boxes with parallel bars representing parallelisms, and crossed bars reversals.

stomata on stems (character 3:1) developed once with a later reversal. Interestingly, the reversal appears in a clade where the vegetative parts are covered in appressed parallel hairs (character 9:1), indicating that hairs have taken over the function of protection against excessive evaporation. The taxa with appressed parallel hairs, $C$. spinosus, $C$. incanus, $C$. anisotrichus and C. parviflorus, are all restricted to Somalia, with the exception of $C$. spinosus, which is also found on Socotra and the adjacent island of Abd el Kuri. A much-branched habit (character 1:1) has developed once in Campylanthus; this appears to be coupled to the development of spinescent branches (character 2:1).

Corolla evolution in Campylanthus is a bit ambiguous. Corolla tubes longer than $11 \mathrm{~mm}$ (character 18:1) are found only in C. chascaniflorus (Oman), C. somaliensis (Somalia) and C. antonii (Yemen), which are placed in ascending order in the topology. From a biogeographical point of view it seems fairly unlikely that this 
character has developed only once, with a later reversal; a more likely scenario would be that it has developed independently three times in these taxa.

A complete analysis of Campylanthus using molecular data would certainly help to improve the understanding of character evolution in the genus. However, until such a study is performed, and given the fact that the analysis presented above is based solely on morphological characters, one must be very cautious when speculating on character evolution. Also, the fact that the support for most branches is low further weakens such discussion.

\section{BIOGEOGRAPHY}

The genus Campylanthus is distributed in the Canary Islands, Cape Verde Islands, northeast tropical Africa, southern Arabia and Pakistan, with a centre of diversity in northeast tropical Africa and southern Arabia, where 12 of the 15 species occur.

The known distributions of all species of Campylanthus are given in Figs 6-8. Note that one dot may represent more than one collection.

Campylanthus is confined to arid regions, and the species are generally found in rocky, gravelly or sandy places. They can be found at altitudes from sea level up to about $2500 \mathrm{~m}$.

The 15 species of Campylanthus have been grouped according to their distribution within floristic regions. For the species occurring on the Cape Verde Islands and the Canary Islands I have used the same circumscription of Macaronesia as that used by, for example, Engler (1882), Bramwell (1972), Sunding (1979) and Takhtajan (1986). The African and Arabian species have been arranged according to the regions proposed by White (1983) and the revised circumscription of the Somalia-Masai

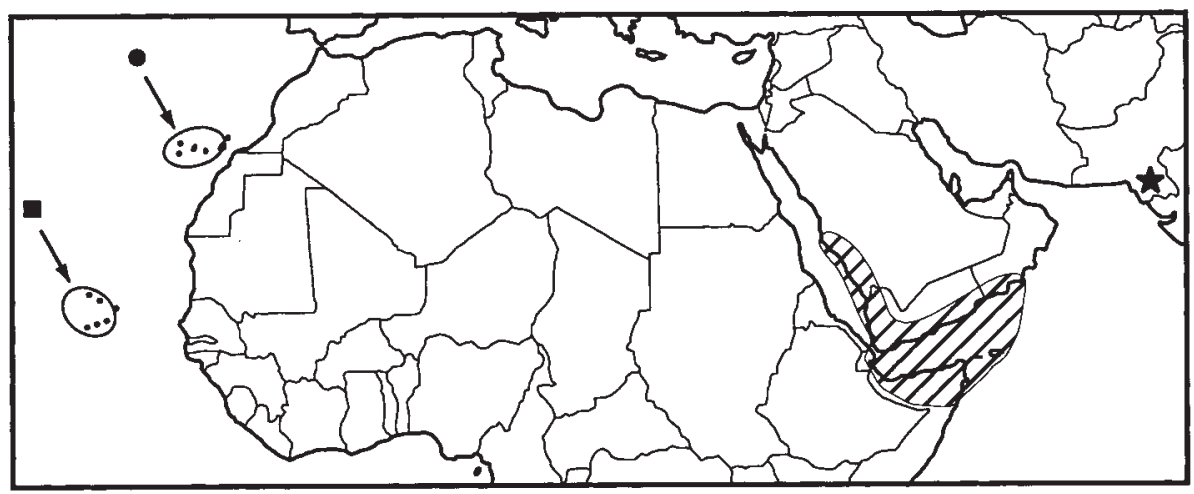

FIG. 6. Map of northern Africa and the Middle East showing total distribution of the genus Campylanthus. Hatched area: 12 species presented in more detail in Figs 7-10. C. glaber (ם), C. salsoloides $(\bullet)$, and C. ramosissimus $(\star)$. 


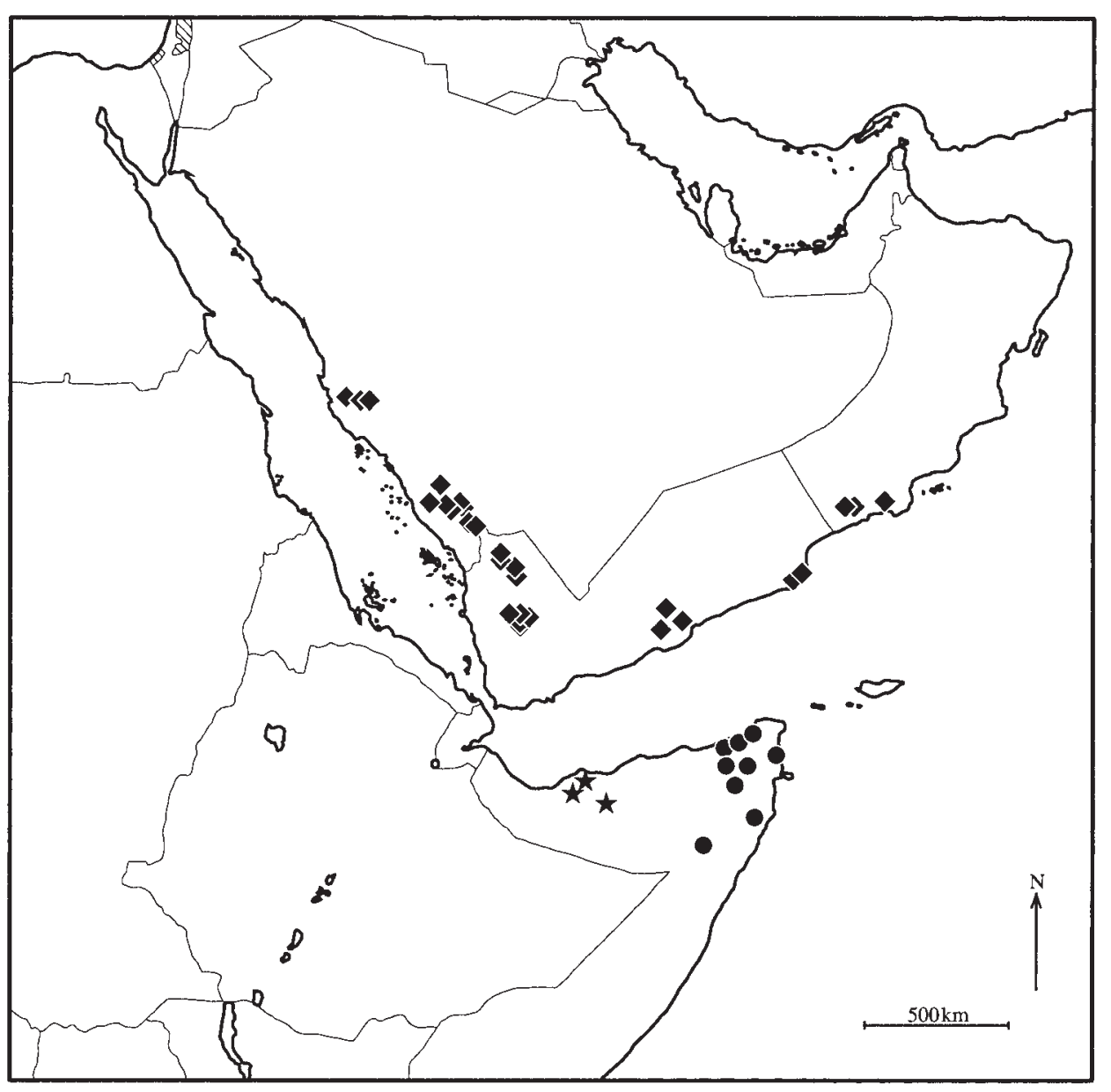

FIg. 7. Map of the Arabian peninsula and NE Africa showing distribution of C. anisotrichus $(\star)$, C. incanus $(\bullet)$, and C. pungens $(\bullet)$.

region of White \& Léonard (1991). For the Pakistani species I have used the Saharo-Sindian region as defined by White \& Léonard (1991). The species have been divided into the following groups: the Macaronesian group, the Somalia-Masai group, and finally the Saharo-Sindian group.

\section{Macaronesian group}

Two species are known from this region, $C$. glaber from the Cape Verde Islands and C. salsoloides from the Canary Islands (Fig. 6). These two species are the western outliers of the genus and they show a remarkable disjunction with the rest of the species, which occur in the Horn of Africa region and Pakistan. Similar patterns of 


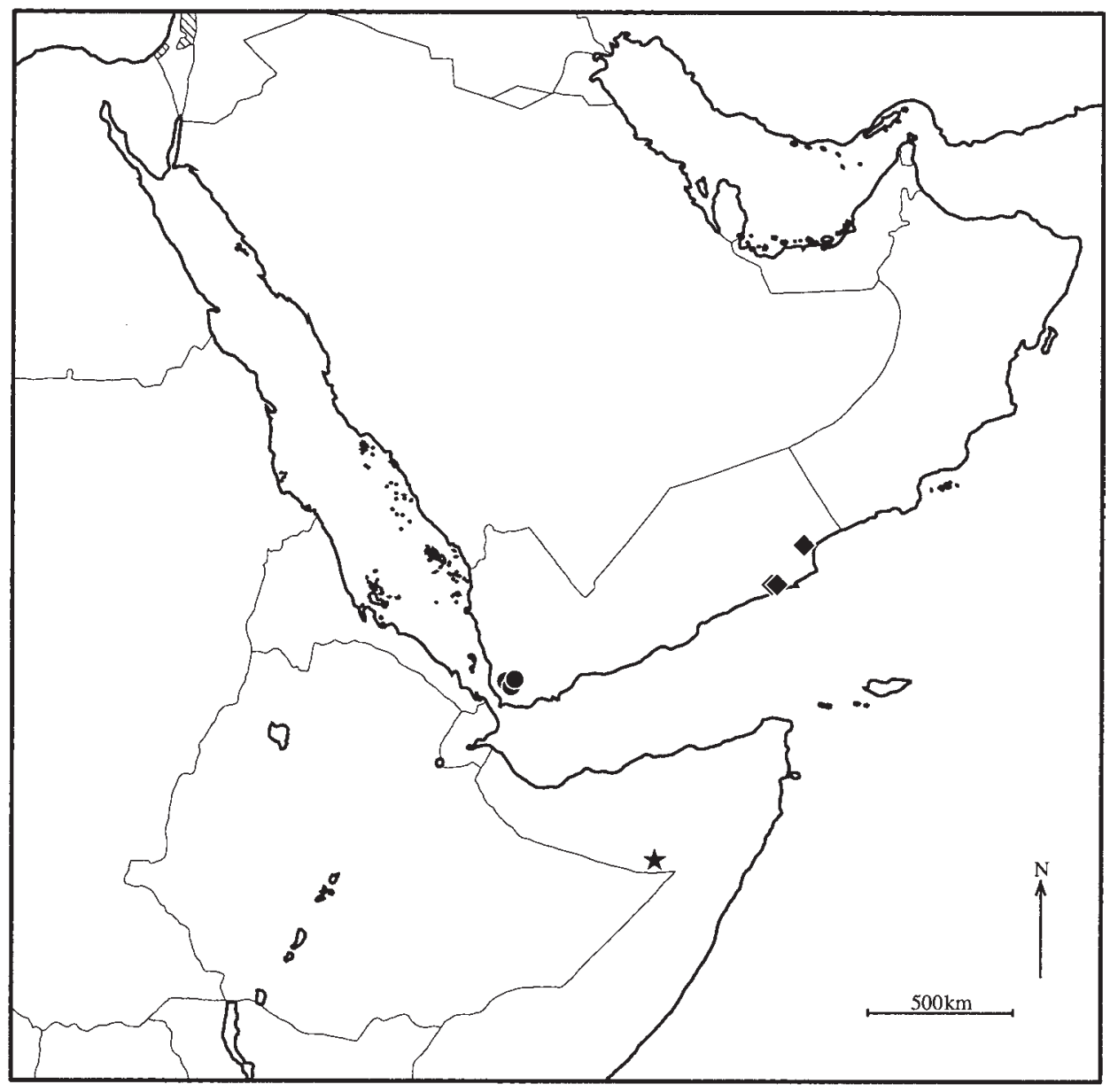

FIG. 8. Map of the Arabian peninsula and NE Africa showing distribution of C. parviflorus $(\star)$, C. yemenensis $(\bullet)$, and C. antonii

distribution are also known in other taxa, for example Aeonium Webb \& Berthel. (Lems, 1960; Liu, 1989), Dracaena Vand. ex L. (Sunding, 1979), Drusa DC. (Hedge \& Miller, 1977), and Euphorbia balsamifera Aiton (Bally, 1965).

The endemic Macaronesian flora is at least partly considered to be a relic of the Tethyan-Tertiary Region (e.g. Meusel, 1953; Bramwell, 1976). It is thus quite logical to argue that some of the disjunct elements in the Horn of Africa region are also relics of the same time, as stated by Thulin (1994). The reason for the disjunctions between the two opposite sides of Africa may be found in the spreading of a drier climate in Africa during the late Miocene (Axelrod, 1975), eliminating populations between these two outposts. 


\section{Somalia-Masai group}

The vast majority of the species, namely $C$. anisotrichus, $C$. antonii, $C$. chascaniflorus, C. incanus, $C$. junceus, C. mirandae, C. parviflorus, C. pungens, C. sedoides, C. somaliensis, C. spinosus and C. yemenensis, belong to this region (Figs 7-10), as it was shown by White \& Léonard (1991) that southern Arabia and Socotra with adjacent islands are also part of the Somalia-Masai region. However, the delimitation of floristic regions in Arabia has been disputed, and in the work of Zohary (1973), using another terminology, the Arabian species would be placed in the large Sudanian region, which includes the Somalia-Masai region of White \& Léonard (1991). The Sudanian region of Zohary was later enlarged by Mandaville (1984) to include most of the Arabian peninsula.

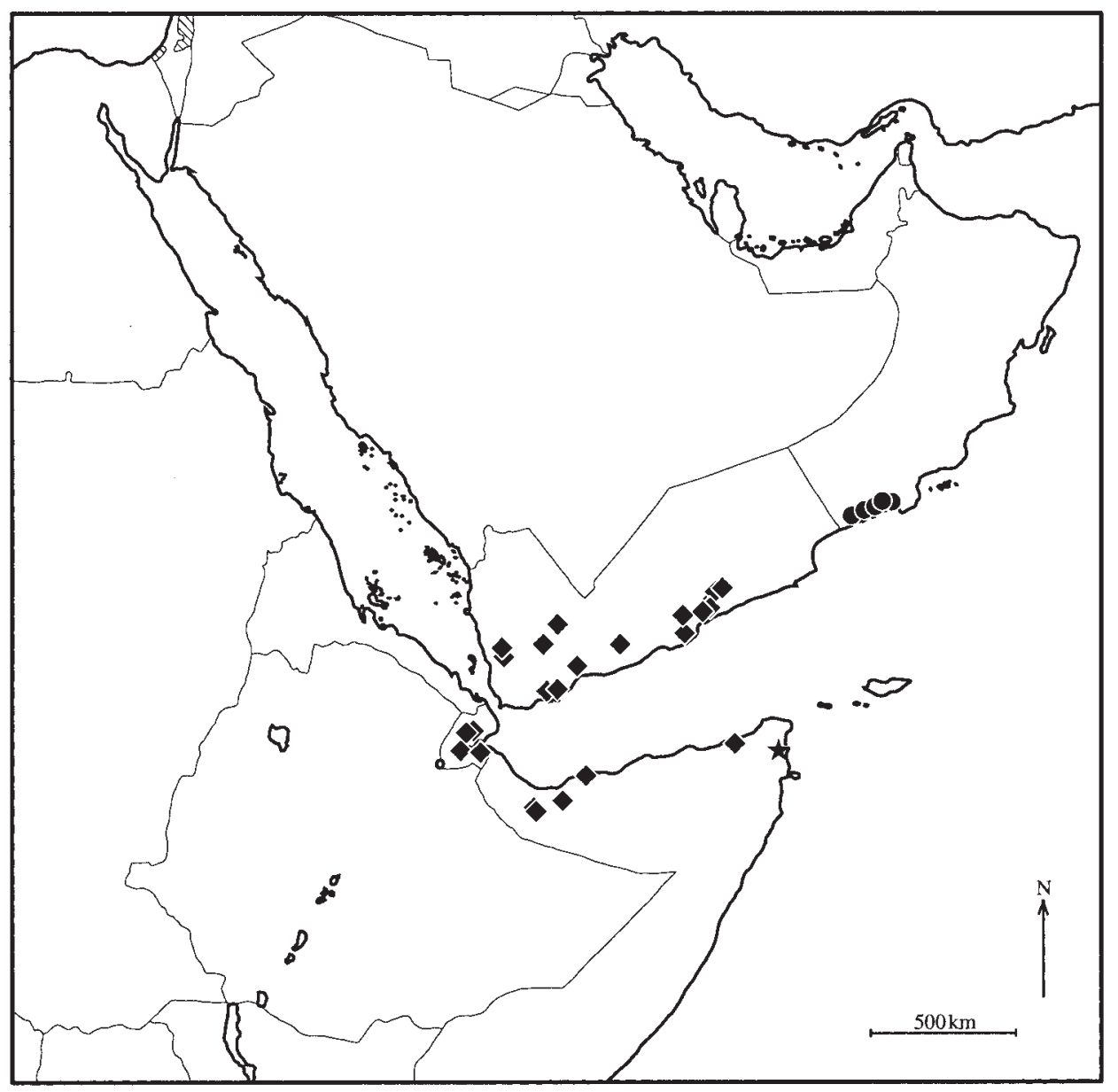

FIg. 9. Map of the Arabian peninsula and NE Africa showing distribution of C. somaliensis $(\star)$, C. chascaniflorus $(\bullet)$, and $C$. junceus $(\bullet)$. 


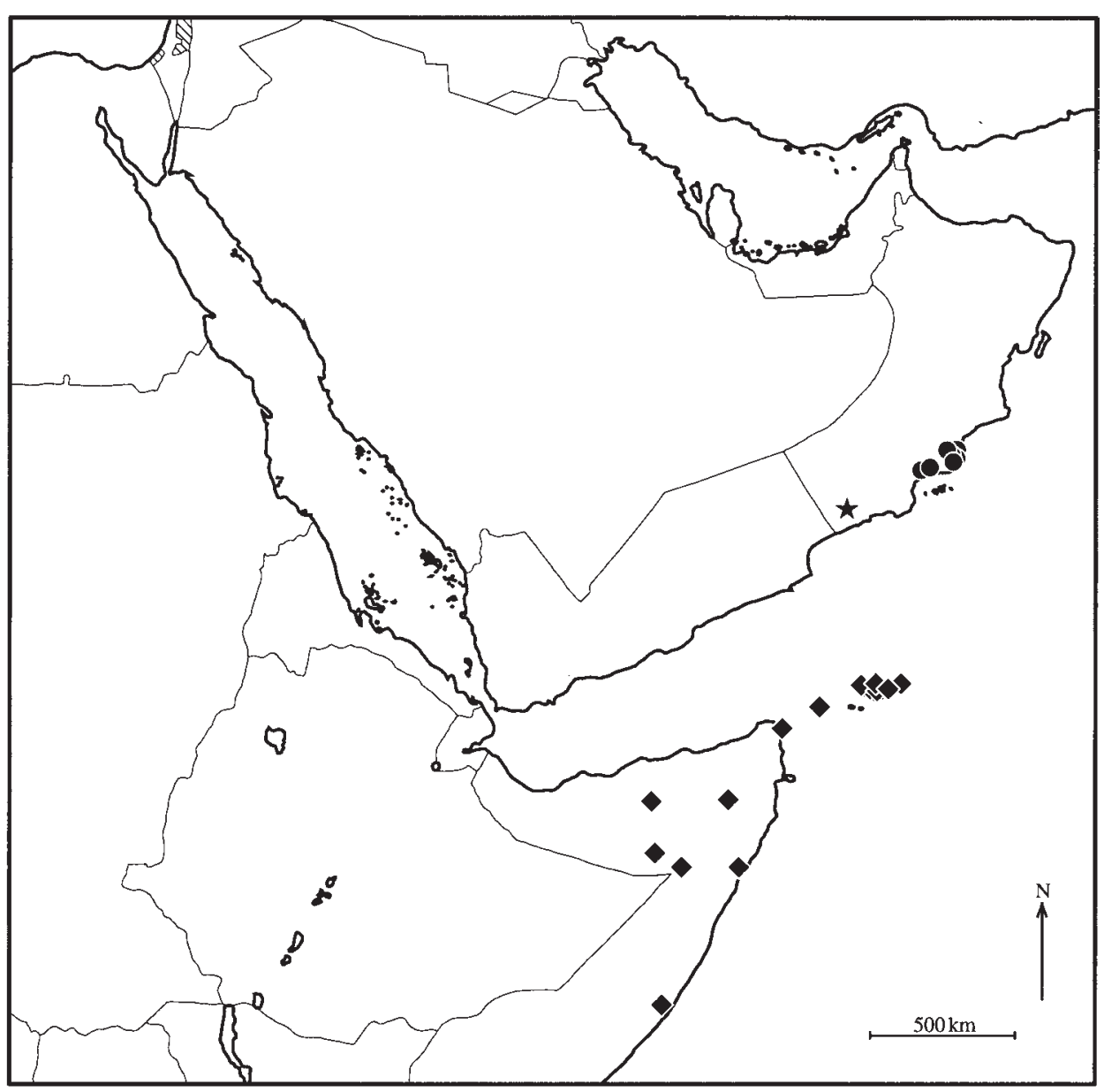

FIG. 10. Map of the Arabian peninsula and NE Africa showing distribution of C. mirandae $(\star)$, C. sedoides $(\bullet)$, and C. spinosus $(\bullet)$.

Most species in Africa and Arabia have strongly restricted distributions, the only exceptions being C. pungens in Saudi Arabia, Yemen and Oman, C. spinosus on Socotra and the adjacent Abd el Kuri and in eastern Somalia, and C. junceus, which is the only species that occurs on both sides of the Gulf of Aden.

Miller \& Nyberg (1991) recognized eight local centres of endemism on the Arabian peninsula, apart from Socotra and neighbouring islands. Campylanthus yemenensis has a distribution just outside their local area of endemism around Ibb in northern Yemen, an area that is very rich in endemics. Campylanthus antonii is found in the Jol area that corresponds to the Hadramaut and Mahra Governorates in southeastern Yemen which contains about 40 endemics. In Oman C. chascaniflorus and C. mirandae both occur within the local area of endemism in Dhofar (c.35 endemics), 
while $C$. sedoides is found in the floristically poor region of Central Oman which has about 15 endemics.

Socotra and neighbouring islands constitute an area well known for its many endemics, which account for $30 \%$ of the total flora, or 240 species (Miller \& Nyberg, 1991). Campylanthus spinosus was long considered endemic on Socotra and Abd el Kuri, but Verdcourt (1958) reported a collection made in Somalia in 1956 (Simmons B50). However, the first collection in Somalia had already been made in 1924 by Stefanini \& Paoli, and this collection later became the type of Chamaeacanthus pumilus Chiov. (Chiovenda, 1929), a name now placed in the synonymy of $C$. spinosus (Miller, 1982).

Apart from the relatively widespread $C$. junceus and C. spinosus, all species occurring in Africa have strongly restricted distributions. Of these, C. somaliensis is found in the northeastern corner of Somalia, which is one of the two areas in this country pointed out by Thulin (1994) to be particularly rich in endemics. Most collections of $C$. incanus are also from this area, but its distribution also extends further south. Campylanthus anisotrichus is restricted to an area around Berbera in the northwest, which is fairly high in endemics, whereas C. parviflorus occurs near Laascaanood [ $=$ Las Anod], an area with rather few endemic species.

It is interesting to note that the southernmost collection of $C$. spinosus is from near Hobyo, an area which besides its many endemics also has disjunct distributions of otherwise north-Somalian taxa, for example Buxus hildebrandtii Baill. and Maytenus undulata (Thunb.) Blakelock (Thulin, 1994).

\section{Saharo-Sindian group}

According to the definition of White \& Léonard (1991) only one species belongs to this region, namely C. ramosissimus from Sind in southeast Pakistan. Among species endemic to this area (Pakistan and northern India) Moringa concanensis Nimmo can be mentioned and perhaps also M. oleifera Lam., although the distribution of the latter has been much extended by cultivation (Verdcourt, 1985). Moringa, like Campylanthus, is disjunct between Sind and northeast tropical Africa/Arabia, where nine of the 14 species occur (Thulin, 1994). The phytogeographical link between the Somalia-Masai region and Sind was also discussed by Thulin (1985).

\section{Vicariance biogeography}

Originally, Campylanthus might have been more or less evenly distributed throughout northern Africa, and the present disjunction between Macaronesia and the Horn of Africa region was most likely caused by extinctions in the area between these regions when the climate became drier as discussed above. This hypothesis is congruent with the phylogeny of the genus, which indicates a basal split between western and eastern species.

Of the five archipelagos in Macaronesia, the Cape Verde Islands is the one that 
differs most from the other four with respect to the total vascular flora and phytogeographical spectrum (Sunding, 1979). However, apart from Campylanthus, the Cape Verde Islands also host a considerable number of taxa, for example Dracaena draco L., Sideroxylon marmulano Banks ex Lowe, and species of Aeonium Webb \& Berth., Echium L. and Sonchus L., that are identical to or related to those of the Canary Islands or Madeira, supporting the inclusion of the Cape Verde Islands in the biogeographic region of Macaronesia (Sunding, 1979).

The species occurring in northeast Africa, Arabia and Pakistan, with the exception of $C$. junceus, $C$. pungens and $C$. spinosus, largely show a vicariant pattern of distribution. It has been shown that during the Paleocene Africa was connected to Asia via Arabia (Raven \& Axelrod, 1974). It is quite possible that Campylanthus had a more or less even distribution from what is now Macaronesia in the west to Sind in the east. The subsequent continental break up forming the Red Sea, the Gulf of Aden and the Persian Gulf, along with further vicarious events followed by speciation, then formed the basis of the picture we see today. The only species occurring on both sides of the Gulf of Aden, C. junceus, is also partially sympatric with the closely related $C$. pungens in Arabia as well as with $C$. anisotrichus in Somalia. This distribution is probably due to secondary dispersal. Campylanthus pungens, in turn, is also partially sympatric with $C$. chascaniflorus and C. mirandae in Oman.

In the strongly supported clade comprising $C$. anisotrichus, C. incanus, C. parviflorus and $C$. spinosus all species are allopatric except for $C$. spinosus which may have dispersed to Somalia from the Socotra archipelago.

\section{TAXONOMY}

\section{Materials and methods}

This work is based mainly on herbarium material obtained on loan from or studied in the following herbaria: B, BM, BONN, BR, EA, FT, HBG, K, O, P, UPS, W, WAG and WU (abbreviations according to Holmgren et al., 1990). Field work was performed in southern Yemen in 1992, where Campylanthus junceus Edgew., C. pungens $\mathrm{O}$. Schwartz and $C$. antonii Thulin were studied.

Morphology. Plant parts were measured with a hand-ruler or under a dissecting microscope. Flowers were softened in hot water before dissection. Seeds and various hair types were studied by light microscopy (LM) or scanning electron microscopy (SEM). For the SEM studies seeds and small pieces of stems were put on doublesided adhesive tape on stubs and coated with gold-palladium.

Maps. The distribution maps were computer-drawn using CANVAS 5.0.2 for Macintosh.

Species concept. Since this study is based mainly on herbarium material, a morphological species concept has been applied. Species concepts, especially the morphological, are discussed by several authors (DuRietz, 1930; Cronquist, 1978; Stuessy, 1990). 
Collection lists. Type specimens are not repeated in the collection lists. Names of localities have been used in accordance with various gazetteers as far as possible. Altitudes, where originally given in feet, have been transformed into metres. All collections cited have been seen by the author, unless otherwise stated.

Campylanthus Roth, Nov. Pl. Sp. 4 (1821).

Type: Campylanthus salsoloides (L.f.) Roth.

Syn.: Chamaeacanthus Chiov., Flora Somala: 266 (1929). Type: Chamaecanthus pumilus Chiov.

Shrubs, subshrubs or woody-based perennial herbs; stems terete, erect to decumbent, often much branched, sometimes with spine-tipped branches, almost glabrous to pilose or hirsute. Leaves simple, alternate, sessile to subsessile, subulate to distinctly flattened, often succulent, entire. Flowers white to purplish or pinkish-brown, pedicellate or subsessile, arranged in terminal, few- to many-flowered racemes; bracts usually leaf-like and similar to the ordinary leaves. Bracteoles 2, inserted at the base of the pedicel. Calyx with 5 more or less equal lobes. Corolla hypocrateriform to infundibuliform; lobes 5, subequal; tube cylindric with two geniculations, glabrous or pilose to hirsute outside, pilose with antrorse hairs above the insertion of the stamens and glabrous or more commonly with erect to retrorse hairs below the insertion of the stamens inside. Stamens 2, anterior; filaments filiform, inserted in the corolla tube at the upper geniculation, glabrous; anther thecae fully confluent with a slight constriction in the middle, longitudinally dehiscent. Ovary ovoid; style filiform, glabrous; stigma capitate, oblique. Capsule laterally compressed, orbicular to ovate in outline, septicidally dehiscent. Seeds numerous, discoid, with a scarious wing around the margin, sometimes in the funicular region only; embryo curved, peripheral.

\section{Key to the species}

1a. Plants with parallel, bifurcating hairs 2

1b. Plants glabrous, at least above, or with unbranched hairs only 4

2a. Bifurcating hairs with arms of equal length 13. C. incanus

2b. Bifurcating hairs with one arm distinctly shorter than the other 3

3a. Flowers to $4 \mathrm{~mm}$ long, white; stems divaricately branched in three or more orders 15. C. parviflorus

$3 \mathrm{~b}$. Flowers at least $6 \mathrm{~mm}$ long, purple; stems divaricately branched in two orders 14. C. anisotrichus

4a. Plants with glandular hairs 5. C. somaliensis

4b. Plants glabrous, at least above, or with eglandular hairs 5

5a. Corolla tube at least $14 \mathrm{~mm}$ long __ 6

5b. Corolla tube to $10 \mathrm{~mm}$ long _ 7

6a. Virgate, almost leafless shrub; glabrous, at least above 6. C. antonii 
6b. Ascending, woody-based herb, distinctly leafy; shortly hirsute to villous

\section{C. chascaniflorus}

7a. Corolla shortly hirsute to hirsute or shortly sericeous outside 8

7b. Corolla glabrous outside 11

8a. Corolla shortly sericeous; plants shortly sericeous, silvery grey 12. C. spinosus

8b. Corolla shortly hirsute to hirsute; plants glabrous or shortly hirsute, never silvery grey 9

9a. Shrubs to $2 \mathrm{~m}$ tall, distinctly leafy, leaves $10-50 \mathrm{~mm}$ long 2. C. salsoloides

9b. Dwarf shrubs to $20 \mathrm{~cm}$ tall, leaves to $8 \mathrm{~mm}$ long 10

10a. Plants subaphyllous, branches \pm spinescent; corolla mauve 11. C. yemenensis

10b. Plants with succulent, broadly elliptic to obovate or spathulate leaves; branches not spinescent; corolla pink to reddish-brown

3. C. sedoides

11a. Plants densely sericeous, silvery grey; distinctly spinescent __ 12. C. spinosus

11b. Plants glabrous or with a different indumentum, never silvery grey 12

12a. Virgate shrub to $2 \mathrm{~m}$ tall; geniculations of the corolla tube very prominent and well exserted from the calyx

7. C. junceus

12b. Shrubs or dwarf shrubs to $1 \mathrm{~m}$ tall; geniculations of the corolla tube not very prominent, positioned at mouth of calyx

13a. Leaves at least $10 \mathrm{~mm}$ long (usually much longer) 1. C. glaber

13b. Leaves to $7 \mathrm{~mm}$ long 14

14a. Stems and leaves shortly hirsute to shortly pilose 10. C. mirandae

14b. Stems and leaves papillose or glabrous 15

15a. Leaves acute; corolla tube at least $8 \mathrm{~mm}$ long 15b. Leaves obtuse; corolla to $7 \mathrm{~mm}$ long

1. Campylanthus glaber Benth. in DC., Prodromus 10: 508 (1846). Type: Cape Verde Islands, Forbes s.n. (lecto., selected here: K).

Syn.: Campylanthus benthamii Webb in Hooker, Icones Plantarum tab. 776 (1848). Campylanthus benthamii Webb var. glaber (Benth.) Webb in Hooker, Icones Plantarum tab. 776 (1848).

Campylanthus benthamii Webb var. hirsutus Webb in Hooker, Icones Plantarum tab. 776 (1848). Type: Cape Verde Islands, "In montibus ins. S. Vincentii" at 240m, Vogel 72 (lecto., selected by Brochmann et al. (1997): FI-WEBB, not seen; isolecto. $\mathrm{K})$.

Campylanthus glaber Benth. var. puberulus Cout., Arq. Univ. Lisboa 1: 310 (1914). Type: Cape Verde Islands, Santo Antão, iv-v 1894, Cardoso s.n. (holo. LISU, not seen).

Campylanthus spathulatus A. Cheval., Rev. Bot. Appliq. 15: 897 (1935). Type: Cape Verde Islands, Santo Antão, between Pombas and Janela, 11 ix 1934, Chevalier 45278 (holo. P, not seen). 
Campylanthus glaber Benth. ssp. spathulatus (A. Cheval.) Brochmann, N. Kilian, Lobin \& Rustan, Sommerfeltia 24: 277 (1997).

Campylanthus glaber Benth. var. pumilus Pett., Comm. Biol. Soc. Scient. Fenn. 22: 43 (1960). Type: Cape Verde Islands, São Nicolau, 9 xii 1953, H. Lindberg s.n. (holo. H, not seen).

Nomenclatural notes. Two syntypes were mentioned in the protologue of $C$. glaber, Forbes s.n. and Hooker s.n., both of which are at Kew. The single sheet of Hooker s.n. is in rather poor condition compared with the two collections of Forbes s.n. Of the Forbes collections, the one with two plants mounted along with a drawing is in best condition, and is therefore selected as lectotype.

Webb included the older name Campylanthus glaber Benth. in his C. benthamii, and $C$. benthamii is thus superfluous and illegitimate. Furthermore, there has been confusion regarding the correct date of the publication of $C$. benthamii. Most authors have cited Spicilegia Gorgonea (Webb, 1849), included in the Niger Flora (Hooker, 1849 ), as the place of publication. However, that work was published in November or December 1849 according to Stafleu \& Cowan (1979: 298), whereas the first publication of the name was in May 1848 (Stafleu \& Cowan, 1979: 294-295), in Icones Plantarum (Webb, 1848). Webb, who wrote both accounts, obviously intended to publish Spicilegia Gorgonea before the account in Icones Plantarum, but for some reason Spicilegia Gorgonea was delayed. That this was Webb's intention is shown by the fact that he cited Spicilegia Gorgonea in the account in Icones Plantarum.

There are some uncertainties regarding the syntypes of Campylanthus benthamii var. hirsutus. In Spicilegia Gorgonea, where Webb intended to publish the name (see notes above), only Vogel 72 is explicitly stated to belong to var. $\beta$ (=hirsutus), whereas Vogel 35 could possibly be referred to the var. $\beta$ citation given as "(Th. Vogel, n. 35. b. sp. procera et fruct.)". The statement by Brochmann et al. (1997) that Forbes 17 is also a syntype of var. hirsutus is erroneous since no reference to this is made in Spicilegia Gorgonea. Furthermore, Brochmann et al. (1997) wrongly stated that the lectotype of Campylanthus benthamii var. hirsutus was selected by Lobin (1986). In fact Lobin erroneously proposed a lectotype of C. benthamii, which in fact is homotypic with the older $C$. glaber (see notes above). To add to the confusion, Lobin also stated that $C$. benthamii var. hirsutus is homotypic with $C$. benthamii. These errors were pointed out by Brochmann et al. (1997), but they made no attempts to correct them. Therefore I consider that the name was first properly lectotypified by Brochmann et al. (1997).

I have not seen the type of $C$. spathulatus. However, a photograph of the type was included in the protologue (Chevalier, 1935: pl. 14).

I have not seen the types of Campylanthus glaber var. puberulus and C. glaber var. pumilus. However, photographs of the types were reproduced by Lobin (1986: 101, 103).

Description. Shrub to $100 \mathrm{~cm}$ high. Stems erect, branched; young branches leafy, old ones with persistent leaf bases, glabrous to shortly hirsute, particularly at axils. Leaves 
succulent, linear to narrowly elliptic or narrowly obovate, acute, glabrous or sometimes shortly hirsute, $10-55 \times 0.7-7 \mathrm{~mm}$. Flowers c. $10-30$ in simple or somewhat branched racemes to $15 \mathrm{~cm}$ long; pedicels $3-8 \mathrm{~mm}$ long, glabrous to shortly hirsute; bracts $2.5-10 \mathrm{~mm}$ long, glabrous to shortly hirsute; bracteoles $1-5 \mathrm{~mm}$ long, glabrous to shortly hirsute. Calyx lobes narrowly ovate to triangular, acute, $3.5-6 \times 1-1.8 \mathrm{~mm}$, glabrous or sometimes shortly hirsute outside, ciliate. Corolla hypocrateriform to infundibuliform, pink to mauve or sometimes white, glabrous outside; tube $7-10 \times 2 \mathrm{~mm}$, geniculate at level of calyx mouth, with retrorse hairs below insertion of stamens inside; lobes elliptic to broadly obovate, obtuse to acute at apex, $3-7 \times 2.5-7 \mathrm{~mm}$, glabrous. Anthers $1.7-2.3 \mathrm{~mm}$ long; filaments $0.5-1 \mathrm{~mm}$ long. Ovary slightly compressed, tapering abruptly into style. Style $1-2 \mathrm{~mm}$ long. Capsule broadly elliptic to ovate, $3.5-5.5 \times 2.7-3.5 \mathrm{~mm}$, brown to black. Seeds $0.5-0.9 \times 0.6-0.9 \mathrm{~mm}$, reddish brown, winged around margin.

Distribution and habitat. Campylanthus glaber is endemic to the Cape Verde Islands, where it is known from Santo Antão, São Vicente, São Nicolau, Brava, Fogo and Santiago (Fig. 6). It can be found on cliffs, rocky or sandy slopes and gravel from 10 to $1750 \mathrm{~m}$. The greatest altitudinal ranges are found on Santo Antão $(10-1620 \mathrm{~m})$ and Fogo $(50-1750 \mathrm{~m})$, whereas the smallest ranges are found on São Vicente (200-900m) and Brava (60-740m). On São Nicolau (500-1300m) and Santiago $(60-1150 \mathrm{~m})$ the ranges are intermediate.

Variation and taxonomic remarks. Campylanthus glaber is variable in leaf shape, which ranges from linear and c. $0.7 \mathrm{~mm}$ wide to distinctly flattened and up to $7 \mathrm{~mm}$ wide. The wide-leaved form is mainly found at lower altitudes on Santo Antão, and it has been described as $C$. spathulatus. However, since intermediate forms occur on Santo Antão (e.g. Rustan \& Brochmann 1499 and Rustan \& Brochmann 1826) and São Vicente (e.g. Brochmann \& Rustan 762/82), and given the fact that wide-leaved forms also occur in the normally narrow-leaved $C$. junceus and $C$. spinosus, I see no reason to retain $C$. spathulatus at any rank.

Recently, Brochmann et al. (1997) proposed recognition of C. spathulatus as a subspecies of C. glaber. However, since there is considerable infraspecific variation in other genera in the Cape Verde Islands, for example Campanula L. (Figueiredo, 1995) and Kickxia Dumort. (Sutton, 1988; Ghebrehiwet, 2001), and given the facts discussed above, I cannot agree with their conclusion. If $C$. spathulatus is to be retained as an infraspecific taxon of $C$. glaber, one must recognize infraspecific taxa in several other species of Campylanthus as well and this would serve no useful purpose.

The plants described as C. glaber var. puberulus and C. glaber var. pumilus fall well within the range of $C$. glaber and do not merit recognition.

In the latest revision of the genus (Miller, 1980), C. glaber was treated as a synonym of $C$. salsoloides, the two species being very similar. Campylanthus glaber differs however in the glabrous outer surface of the corolla (distinctly pilose in $C$. salsoloides) and to some extent the more low growing habit. 
Selected specimens (from 125 examined). CAPE Verde IsLands. Santo Antão: NE facing, steep coastal cliffs between Ribeira Paul and Ribeira das Pombas, 10-50m, 21 xii 1993, Kilian \& Leyens 2803 (BONN); Ribeira do Paul, along levada on NW-side of Tope Cavaleiro, $17^{\circ} 07^{\prime} \mathrm{N}$, $25^{\circ} 02^{\prime} \mathrm{W}, 350 \mathrm{~m}, 11$ i 1982, Rustan \& Brochmann 1499 (O); Morossos, between the old crater Espadana and Monte Morossos, steep NE facing escarpments into Ribeira da Garca, 1300 1620m, 23 xii 1993, Kilian \& Leyens 2887 (BONN). São Vicente: NNE of Mindelo, at the top of Monte Vigia, $16^{\circ} 54^{\prime} \mathrm{N}, 2^{\circ} 59^{\prime} \mathrm{W}, 300 \mathrm{~m}, 5$ ii 1982, Rustan \& Brochmann 2108 (O); Monte Verde, 400-500m, 4 xii 1985, Kilian 774 (B); Near the top of Monte Verde, 750m, 1976, Sunding 3357 (O); Tope da Caixa, $16^{\circ} 49^{\prime} \mathrm{N}, 25^{\circ} 00^{\prime} \mathrm{W}, 300 \mathrm{~m}, 6$ ii 1982, Brochmann \& Rustan $762 / 82$ (O). São Nicolau: Monte Gordo, at the top, $16^{\circ} 37^{\prime} \mathrm{N}, 24^{\circ} 21^{\prime} \mathrm{W}, 1300 \mathrm{~m}, 29$ i 1982 , Rustan \& Brochmann $1865(\mathrm{O})$; E part, small peak just $1 \mathrm{~km}$ W of Tope Julanga, $16^{\circ} 35^{\prime} \mathrm{N}$, $24^{\circ} 06^{\prime} \mathrm{W}, 500-550 \mathrm{~m}, 14$ vi 1994, Kilian \& Leyens 3186 (BONN); On the coastal road immediately before Vila da Ribeira Brava, 12 x 1979, Lobin 1016 (BONN, O). Brava: NW-slope of Monte Gambia between Ponta do Sorno and Ponta do Gambia, $14^{\circ} 53^{\prime} \mathrm{N}, 24^{\circ} 43^{\prime} \mathrm{W}, 80 \mathrm{~m}, 26$ ii 1982, Rustan \& Brochmann 2584 (O); Ribeira da Fajã de Agua, along levada close to Ribeira Pau do Corro, $14^{\circ} 51^{\prime} \mathrm{N}, 2^{\circ} 44^{\prime} \mathrm{W}, 230 \mathrm{~m}, 22$ ii 1982, Brochmann \& Rustan 1104/82 (O); S of

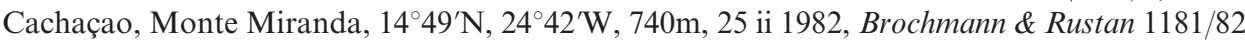
(O). Fogo: Chã das Caldeira, between the village and the "exit" to Monte Velha, 1600-1750m, 24 i 1994, Kilian \& Leyens 3337 (BONN); N of São Filipe, W of Monte Almada on the plains near Ribeira do Pico, $14^{\circ} 55^{\prime} \mathrm{N}, 2^{\circ} 30^{\prime} \mathrm{W}, 80 \mathrm{~m}, 14$ ii 1982, Rustan \& Brochmann 2243 (O); Ribeira São Jorge, between Galinheiros and São Jorge, somewhat above road, 150-200m, 21 i 1994, Kilian \& Leyens 3260 (BONN). Santiago: Serra da Malagueta, $1 \mathrm{~km}$ E of Quebrada, $15^{\circ} 10^{\prime} \mathrm{N}, 23^{\circ} 41^{\prime} \mathrm{W}, 60 \mathrm{~m}, 20$ xii 1981, Brochmann \& Rustan 454/81 (O); SW slope of Serra do Pico da Antonia, SW of Ribeira Longueira, 1100m, 18 xi 1976, Sunding 3710 (O); The more western of the two volcano cones between Ribeira São João and Ribeira Fundura, in the upper slopes on the Ribeira Fundura NW below the volcano cone, $14^{\circ} 59^{\prime} \mathrm{N}, 23^{\circ} 41^{\prime} \mathrm{W}$, 400-460m, 13 xii 1993, Kilian \& Leyens 2699 (BONN).

2. Campylanthus salsoloides (L.f.) Roth, Nov. Pl. Sp. 4 (1821). Type: Canary Islands, Tenerife, "Habit in Barrancas circa oppidum St. Crux", 1778, Masson s.n. (lecto., selected by Miller (1980): BM; isolecto. UPS-THUNB.).

Syn.: Eranthemum salsoloides L.f., Suppl. Pl. 82 (1782).

Teucrium filiforme Poir., Encycl. (Lamarck) Suppl. 2: 769 (1812). Type: Canary Islands, Broussonet s.n. (P?, not seen).

Campylanthus salsoloides (L.f.) Roth var. penduliflorus Pitard in Pitard \& Proust, Flore de l'Archipel les Iles Canaries 293 (1909). Type: Gran Canaria, Guia, Barranco de San Felipe, 200m, Pitard 1577 (lecto., selected here: P).

Campylanthus salsoloides (L.f.) Roth var. leucanthus Svent., Indices Seminum Horti Acclimat. Plantarum Arautapensi 4: 47 (1967). Nom. inval. (Art. 37.1).

Nomenclatural notes. There is one sheet of Campylanthus salsoloides in the Thunberg herbarium at UPS under the name Selago salsoloides. The fact that the specimen was collected by Fr. Masson (see reverse of sheet) and that it is very similar to the lectotype in BM makes it clear that this represents an isolectotype of Eranthemum salsoloides. The locality data in the protologue says: “...circa oppidum...", whereas the label on the sheet in question says: "...prope oppidum...".

I have seen only the protologue of Teucrium filiforme Poir., but according to Webb 
\& Berthelot (1845), who had seen the appropriate material, it belongs to Campylanthus salsoloides.

Pitard (1909) did not cite any specimens in the protologue of $C$. salsoloides var. penduliflorus, but a detailed locality description was given. There are two sheets present in P: Pitard 1577 and Pitard 1578, both collected in Barranco de San Felipe, Gran Canaria. The data given on the label of Pitard 1577 conform most closely with the protologue and this sheet is therefore selected as lectotype.

Sventenius (1967) did not cite a type for C. salsoloides var. leucanthus, and thus the name is not validly published.

Description. Shrub to $200 \mathrm{~cm}$ high. Stems erect, branched; young branches leafy, old ones with persistent leaf bases, glabrous to shortly hirsute above, particularly at axils. Leaves succulent, linear, more or less terete, acute, glabrous, $10-50 \times 0.8-2 \mathrm{~mm}$. Flowers c.10-30 in simple or somewhat branched, hirsute racemes to $20 \mathrm{~cm}$ long; pedicels $3.5-6.5 \mathrm{~mm}$ long, hirsute; bracts $2.5-6 \mathrm{~mm}$ long, hirsute; bracteoles 1.3-2.5mm long, hirsute. Calyx lobes narrowly ovate to triangular, acute, 4-6 $\times 1.5-2 \mathrm{~mm}$, hirsute outside, ciliate. Corolla hypocrateriform to infundibuliform, pink to mauve, or sometimes white, shortly hirsute outside; tube $7-9 \times 1.5-2 \mathrm{~mm}$, geniculate at level of calyx mouth, with retrorse hairs below insertion of stamens inside; lobes elliptic to broadly obovate, obtuse to acute at apex, $3.5-7.5 \times 3-4 \mathrm{~mm}$, shortly hirsute outside. Anthers $2.2-2.5 \mathrm{~mm}$ long; filaments $0.5-0.7 \mathrm{~mm}$ long. Ovary ovoid, slightly compressed, tapering abruptly into style. Style $1-1.5 \mathrm{~mm}$ long. Capsule broadly elliptic to ovate, $4-6.5 \times 3.5-4 \mathrm{~mm}$, brown to black. Seeds $0.8 \times 0.9-1 \mathrm{~mm}$, reddish brown, winged around margin.

Distribution and habitat. Campylanthus salsoloides is endemic to the Canary Islands, where it is found on Gran Canaria, Gomera, Fuerteventura and Tenerife (Fig. 6). It grows on cliffs, on rocky slopes and hillsides, and on dry banks from 10 to $660 \mathrm{~m}$. Associated plants include Asparagus umbellatus Link, Euphorbia canariensis L. and Periploca laevigata Aiton.

Variation and taxonomic remarks. Campylanthus salsoloides is a uniform species, showing some variation only in leaf length and colour of the corolla. The plant described as C. salsoloides var. penduliflorus is merely a form with hanging inflorescences, and it is not worth retaining at any rank.

Campylanthus salsoloides is closely related to the very similar C. glaber from the Cape Verde Islands. For differences between the two, see under $C$. glaber.

Selected specimens ( from 117 examined). CANARY IsLANDS. Fuerteventura: Risco Blanco, about $1.5 \mathrm{~km} \mathrm{~S}$ of Vega de Rio Palmas, 470m, 28 iii 1979, Halvorsen 103 (O). Gomera: Agula, 150m, 19 ix 1924, Czeczott 216 (K); Just before Tamargada on road from Vallehermoso to Hermigua, 450m, 9 iii 1973, Aldridge 1138 (BM); Puerto de Hermigua, 150m, 3 iv 1957, Lid s.n. (O). Gran Canaria: Cuesta de Silva, 23 v 1933, Asplund 1368 (K, O, UPS); Caldera de Bandama, 400-500m, 17 v 1900, Bornmüller 1037 (HBG, W, WU); Barranca de Tirajana on cliffs SW of Temisas, 600m, 20 iii 1971, Bramwell \& Humphries 3028 (BM). Tenerife: NW part, 2km WNW of Buenavista near the seashore, 17 iv 1974, Moberg 2231 (UPS); Montañas de Teno, 
Punta de Teno, $28^{\circ} 21^{\prime} \mathrm{N}, 13^{\circ} 12^{\prime} \mathrm{W}, 50 \mathrm{~m}, 8$ iv 1977, Jarvis \& Murphy 197 (BM); Guimar, Mirador de Don Martin, $28^{\circ} 17^{\prime} \mathrm{N}, 1^{\circ} 24^{\prime} \mathrm{W}, 20$ iii 1997, Swenson, Schmidt \& Almeida 478 (UPS).

3. Campylanthus sedoides A.G. Mill., Notes Roy. Bot. Gard. Edinburgh 38: 382, fig. 2a \& 5Aa-e (1980). Type: Oman, Dhofar, Shuwamiyah, in shallow sand over rocky ledges, 50m from high tide mark, 0m, 14 x 1979, Miller 2727 (holo. E).

Description. Subshrub to $20 \mathrm{~cm}$ high. Stems procumbent; young branches greyishgreen often tinged red, hirsute; old branches light yellowish brown with \pm peeling bark, glabrescent. Leaves succulent, broadly elliptic to broadly obovate or spathulate, obtuse, shortly hirsute to hirsute, $1.5-8 \times 1.5-4 \mathrm{~mm}$. Flowers $2-4$ at ends of branches; pedicels $0.5-1(-2) \mathrm{mm}$ long, hirsute; bracts $1.5-3 \times 0.8-3 \mathrm{~mm}$, hirsute; bracteoles $1-2.5 \times 0.8-2.5 \mathrm{~mm}$, hirsute. Calyx lobes narrowly elliptic to narrowly triangular, acute, $2.5-5.5 \times 0.8-1.5 \mathrm{~mm}$, hirsute. Corolla hypocrateriform, pink to reddishbrown, hirsute outside above the upper geniculation; tube $6.5-9 \times 1-1.5 \mathrm{~mm}$, geniculate at level of calyx mouth, with retrorse hairs below insertion of stamens inside; lobes furrowed in middle at apex, broadly obovate, acute at apex, 2.5-3.5 $\times 2.2-3.2 \mathrm{~mm}$, hirsute outside. Anthers $1.6-2.2 \mathrm{~mm}$ long; filaments c. $0.5 \mathrm{~mm}$ long. Ovary ovoid, slightly compressed, tapering abruptly into style. Style c. $2-4.5 \mathrm{~mm}$ long. Capsule broadly obovoid, 3-5 ×3.7-5mm, brown. Seeds c.0.7-1×1-1.2mm, bluish black, winged around margin.

Distribution and habitat. Campylanthus sedoides is known from coastal areas in Oman from around Shuwamiyah and eastwards to Sawqirah (Fig. 10). It is found on sparsely vegetated sandy beaches or gravel plains between sea level and $600 \mathrm{~m}$.

Vernacular name. Gunerain (Oman, JAS 75).

Variation and taxonomic remarks. Campylanthus sedoides shows no notable variation. It is easily distinguished from all other members of the genus by its dwarfish habit and by its succulent, broadly obovate to spathulate leaves.

Specimens examined. Oman. Dhofar: $19^{\circ} \mathrm{N}, 56^{\circ} \mathrm{E}, 13$ ii 1968, Popov 68/17 (BM); Popov 68/24 (BM); Wadi Ghadun, Sahil al Jazir, $18^{\circ} 45^{\prime} \mathrm{N}, 56^{\circ} 43^{\prime} \mathrm{E}$, 50m, 13 v 1983, Gallagher 6763/10 (E); R'as Sawqirah c.5km W of Sawqirah, 19 ix 1989, Miller \& Nyberg 9451A (E, K); Sawqirah, 0m, 29 ix 1984, Miller 6477 (K); Plateau above Sharbithat, 200m, 19 ix 1989, Miller \& Nyberg 9444 (E, K); Limestone cliffs above Sharbithat, $18^{\circ} 00^{\prime} \mathrm{N}, 56^{\circ} 27^{\prime} \mathrm{E}, 100 \mathrm{~m}, 29$ ix 1984, Miller 6453 (E); Sharbithat, 240km NE of Salalah, 20m, 14 x 1979, Miller 2754 (E); Without precise locality, iv 1989, JAS s.n. (E).

4. Campylanthus chascaniflorus A.G. Mill., Notes Roy. Bot. Gard. Edinburgh 38: 380, fig. 2c \& 5Ba-d (1980). Type: Oman, Dhofar, Ra's Hamar, 6km W of Raysut, on sea cliffs, 50m, 28 ix 1979, Miller 2312 (holo. E).

Description. Perennial woody-based herb to $25 \mathrm{~cm}$ high. Stems prostrate or ascending, branched from below or somewhat branched above; branches greyish-green, shortly hirsute to villous. Leaves obovate to elliptic, obtuse to acute, shortly hirsute to 
villous, $2-18 \times 0.5-7 \mathrm{~mm}$. Flowers c. $4-10$ in \pm secund racemes to $10 \mathrm{~cm}$ long; pedicels $2.5-6(-8.5) \mathrm{mm}$ long, shortly hirsute to villous; bracts $1-4 \mathrm{~mm}$, shortly hirsute to villous; bracteoles $1-2 \mathrm{~mm}$ long, shortly hirsute to villous. Calyx lobes narrowly ovate to narrowly triangular, acute, $0.7-1.2 \times 1.8-4 \mathrm{~mm}$, with narrow scarious margin at least at base, shortly hirsute to villous outside and with villous margins. Corolla hypocrateriform, pinkish yellowish-brown, glabrous outside; tube 14-18 $\times 1 \mathrm{~mm}$, geniculate in the middle, with retrorse hairs below insertion of the stamens inside; lobes recurved, narrowly oblong to narrowly ovate, acute at apex, $4.2-6.7 \times 1-2.5 \mathrm{~mm}$, glabrous. Anthers $2.2-2.5 \mathrm{~mm}$ long; filaments $0.3-0.5 \mathrm{~mm}$ long. Ovary slightly compressed, tapering abruptly into style. Style c. $9 \mathrm{~mm}$ long. Capsule broadly elliptic to round, c. $4-5.5 \times 3-4 \mathrm{~mm}$, brown. Seeds $\mathrm{c} .1 \times 1.2 \mathrm{~mm}$, reddish brown, winged around margin.

Distribution and habitat. Campylanthus chascaniflorus is a common species (Miller \& Morris, 1988) restricted to southwestern Oman (Fig. 9); it can be found on rocky slopes and cliffs, in wadi beds and in coastal sand. The vegetation at the type locality is dominated by Commiphora sp. Other plants associated with C. chascaniflorus include Boswellia sacra Flueck., Ziziphus leucodermis (Baker) O. Schwartz and Aloe dhufarensis Lavranos. The altitudinal range is from sea level to $100 \mathrm{~m}$.

Variation and taxonomic remarks. Campylanthus chascaniflorus is a uniform species, showing some variation in leaf size and indumentum only. It is readily distinguished by its more or less herbaceous habit. In floral characters it is similar only to $C$. antonii, which also has a very long-tubed corolla; however, $C$. antonii is an almost glabrous, virgate shrub with minute leaves. Apart from the illustrations in the protologue, a colour drawing was published in Miller \& Morris (1988: 261, fig. 2A-F).

Specimens examined. Oman. Dhofar: Salalah plain, 5km E of Wadi Hinnah, 10m, 20 ix 1985, Miller 7731 (E); Arzat, near Salalah, $17^{\circ} 00^{\prime}$ N, 54 $4^{\circ} 18^{\prime} \mathrm{E}, 10 \mathrm{~m}, 8$ x 1984, McLeish 68 (E); Wadi Adawnib, near turnoff to Wadi Nar, 30m, 26 v 1985, Miller 7003 (K); Mughsayl, 80km W of Salalah, 10m, 19 x 1979, Miller 2772 (E, K); Kharfat, lower Wadi Sayq, Jabal al Qamar, $9 \mathrm{~km}$ E of Thalfut, $2 \mathrm{~km} \mathrm{~W}$ of Rakhyut, $16^{\circ} 44^{\prime} \mathrm{N}, 53^{\circ} 19^{\prime} \mathrm{E}, 0 \mathrm{~m}, 26$ ix 1977, Radcliffe-Smith 5263 (E, K); Salalah plain, i 1966, Lavranos 4350 (K).

5. Campylanthus somaliensis A.G. Mill., Notes Roy. Bot. Gard. Edinburgh 45: 73, fig. 1Ba-g (1988). Type: Somalia, Bari, 60km S of Bargaal, Tug Giael, 26 xi 1985, Thulin \& Warfa 5560 (holo. UPS; iso. E, K, MOG (destroyed)).

Description. Low shrub to 50cm; most parts with glandular hairs. Stems subaphyllous, ascending, somewhat branched, weakly ribbed, pale green. Leaves linear-oblong, $1.5-10 \times 0.6-1.3 \mathrm{~mm}$, subacute. Flowers $3-8$ in racemes to $7 \mathrm{~cm}$ long; pedicels $2-3 \mathrm{~mm}$ long; bracts ovate, c. $2-2.3 \times 0.5-0.9 \mathrm{~mm}$; bracteoles ovate, $1.5-2 \times 0.5-0.6 \mathrm{~mm}$. Calyx lobes narrowly elliptic to narrowly ovate, acute, $3.5-4.5 \times 0.7-1.5 \mathrm{~mm}$. Corolla hypocrateriform, pale violet with a purple tube, glabrous outside; tube $11-14 \times 1 \mathrm{~mm}$, geniculate in the middle, with retrorse hairs below insertion of stamens inside; lobes obovate, acute at apex, $4.5-6 \times 1.8-3 \mathrm{~mm}$. Anthers c. $2 \mathrm{~mm}$ long; filaments c. $0.5 \mathrm{~mm}$ 
long. Ovary ovoid, slightly compressed, tapering gradually into style. Style c.5-6mm long. Capsule round, c. $4-5.5 \times 4.2-5 \mathrm{~mm}$, brown. Seeds $1.2-1.3 \times 1.8-1.9 \mathrm{~mm}$, purplish brown, wing minute, restricted to funicular region.

Distribution and habitat. Campylanthus somaliensis is known only from the type collection, which was made in northeastern Somalia (Fig. 9). It was found on a limestone slope growing together with Acacia ankokib Chiov., Commiphora sp. and Boswellia frereana Birdw. between 100 and 200m.

Taxonomic remarks. Campylanthus somaliensis is distinguished from all other members of the genus by its dense indumentum of glandular hairs. It differs from the superficially similar $C$. mirandae in the longer corolla tube $(11-14 \mathrm{~mm}$ vs. $7.5-9 \mathrm{~mm})$ and by the longer style (5-6mm vs. $2-2.5 \mathrm{~mm}$ ).

6. Campylanthus antonii Thulin, Nord. J. Bot. 15: 191, fig. 1 (1995). Type: Yemen, Al Mahrah, $13 \mathrm{~km}$ from Sayhut along road to Qishn, $15^{\circ} 15^{\prime} \mathrm{N}, 51^{\circ} 20^{\prime} \mathrm{E}, \mathrm{c} .50 \mathrm{~m}, 16 \mathrm{x}$ 1992, Thulin, Eriksson, Gifri \& Långström 8407 (holo. UPS, iso. K).

Description. Slender shrub to $50 \mathrm{~cm}$ high. Stems subaphyllous, erect, sparsely branched, weakly ribbed, greenish, glabrous above, with short spreading hairs or sometimes shortly pilose with a few longer hairs below. Leaves linear to narrowly elliptic, acute, minutely pubescent or ciliate, lower leaves sometimes shortly pilose with a few longer hairs, $1.5-5 \times 0.5-2 \mathrm{~mm}$. Flowers c.5-13 in racemes to $10 \mathrm{~cm}$ long; pedicels $2-5 \mathrm{~mm}$ long, glabrous; bracts $\mathrm{c} .1 \mathrm{~mm}$, ciliate; bracteoles $\mathrm{c} .0 .8 \mathrm{~mm}$, ciliate. Calyx lobes narrowly ovate, acute, c. $2-3 \times 0.8-1.2 \mathrm{~mm}$, ciliate. Corolla hypocrateriform, brownish yellow, glabrous outside; tube $14-15 \times 1 \mathrm{~mm}$, geniculate in upper third, with retrorse hairs below insertion of stamens inside; lobes linear, recurved, acute at apex, c. $4 \times 1 \mathrm{~mm}$. Anthers c. $1.6 \mathrm{~mm}$ long; filaments c. $0.4 \mathrm{~mm}$ long. Ovary slightly compressed, tapering gradually into style. Style c.10mm long. Capsule broadly elliptic to round, $4-5 \times 4-5 \mathrm{~mm}$, brown. Seeds $1 \times 1.2 \mathrm{~mm}$, purplish brown, wing minute, restricted to funicular region.

Distribution and habitat. Campylanthus antonii is known from a few localities in the Mahrah region in southeastern Yemen (Fig. 8), where it grows on open rocky slopes and along gravelly wadis at altitudes between 5 and $70 \mathrm{~m}$, together with, for example, Ochradenus gifrii Thulin and Isoleucas arabica $\mathrm{O}$. Schwartz.

Variation and taxonomic remarks. The few collections seen show only a little variation in the amount and length of the indumentum. Campylanthus antonii is a distinct species related to $C$. junceus, which is very similar in vegetative characters. However, in floral characters it differs significantly. The corolla tube is much longer in $C$. antonii than in $C$. junceus, the colour is different (brownish yellow in $C$. antonii vs. white to pink to blue in $C$. junceus), as also is the shape of the corolla lobes, which are linear in $C$. antonii and broadly obovate in $C$. junceus. Similar flowers are found in $C$. chascaniflorus from Oman. However, this taxon is a prostrate or ascending perennial herb, with villous vegetative parts and densely set leaves up to $18 \mathrm{~mm}$ long 
and $7 \mathrm{~mm}$ wide. Campylanthus somaliensis from northeastern Somalia is similar in habit but differs in the glandular indumentum and in the violet corolla with the geniculations in the middle of the tube whereas they are in the upper third in $C$. antonii.

Specimens examined. YEMEN. Mahrah: Along road between Al Ghaydah and Al Fatk, $16^{\circ} 30^{\prime} \mathrm{N}$ 52 40'E, 5-20m, 10 xi 1998, Thulin, Beier \& Mohammed A. Hussein 9679 (UPS); $21 \mathrm{~km} \mathrm{NE}$ of Sayhut, $15^{\circ} 16^{\prime} \mathrm{N}, 51^{\circ} 23^{\prime} \mathrm{E}, 10 \mathrm{~m}, 5$ xi 1998, Thulin, Beier \& Mohammed A. Hussein 9534 (UPS); $31 \mathrm{~km}$ NE of Sayhut, $15^{\circ} 18^{\prime} \mathrm{N}, 51^{\circ} 24^{\prime} \mathrm{E}, 70 \mathrm{~m}, 5$ xi 1998, Thulin, Beier \& Mohammed A. Hussein 9539 (UPS).

7. Campylanthus junceus Edgew., J. Asiat. Soc. Bengal 16: 1217 (1847). Type: Yemen, Aden, 19 xii 1847, Hooker 98 (neotype, selected here: K).

Nomenclatural notes. The original material, Edgeworth s.n. (Yemen, Aden, x 1846), was not found in $\mathrm{K}$ where the main set of Edgeworth's material is deposited (Wickens, 1982). Further requests to G and OXF, two herbaria known to hold Edgeworth material (Wickens, 1982), also gave negative results. Finally, a request to CAL confirmed that no material was present there either. It is thus concluded that the original material has been lost, and as a consequence a neotype has been selected. Campylanthus junceus has been collected in Aden many times over the years, and I have selected Hooker 98 (see above) at $\mathrm{K}$ as a neotype, since it matches the original description accurately, dates back to the time of the description of $C$. junceus and is placed in the herbarium where Edgeworth's original material should have been.

Description. Slender shrub to $200 \mathrm{~cm}$ high. Stems subaphyllous, sprawling, somewhat branched, young branches green, old ones brownish-green, glabrous to sparsely pilose, particularly below and at axils. Leaves semi-succulent, linear to elliptic, acute, glabrous to sparsely pilose, $2-22 \times 0.5-2.8 \mathrm{~mm}$. Flowers c. $10-35$ (occasionally fewer) in \pm secund racemes to $30 \mathrm{~cm}$ long; pedicels $2-4.2 \mathrm{~mm}$ long, glabrous; bracts $1-2.6(-5) \mathrm{mm}$ long, glabrous to ciliate, rarely hairy on upper surface as well; bracteoles $0.5-1.7 \mathrm{~mm}$ long, ciliate. Calyx lobes narrowly ovate to ovate, acute, $1.8-4 \times 0.7-1.2 \mathrm{~mm}$, almost glabrous to sparsely pilose inside, usually ciliate. Corolla hypocrateriform, pale to bright blue, pale lilac, mauve, pink or white, glabrous outside; tube $7-10 \times 1 \mathrm{~mm}$, pronouncedly geniculate in the middle, with retrorse hairs below insertion of stamens inside; lobes broadly obovate, obtuse to acute at apex, $2.8-5.5 \times 2.1-4.5 \mathrm{~mm}$, glabrous. Anthers $1.5-1.7 \mathrm{~mm}$ long; filaments $0.3-0.5 \mathrm{~mm}$ long. Ovary slightly compressed, tapering gradually into style. Style $2-5(-7) \mathrm{mm}$ long. Capsule broadly elliptic to round, $4-5.2 \times 3.8-5 \mathrm{~mm}$, brown. Seeds $1-1.3 \times 1.2-1.5 \mathrm{~mm}$, reddish brown, winged around margin.

Distribution and habitat. Campylanthus junceus is distributed in Djibouti and northern Somalia in Africa and in Yemen on the Arabian peninsula (Fig. 9). It is thus the only species of Campylanthus found on both sides of the Gulf of Aden. As well as the three collections cited below, further collections from Djibouti are cited in Moggi (1963: 589) and Lebrun et al. (1989: 208). 
Throughout its distribution, Campylanthus junceus is generally found in rocky places on volcanic ground, but it also grows on sandstone hills, gravel plains and sandy coastal plains. It often grows inside shrubs of, for example, Acacia spp., Indigofera spp. and Leptadenia pyrotechnica Decne. The altitudinal range is from sea level to $2100 \mathrm{~m}$.

Vernacular names. Merko Dabera (Somalia, Gillett 4775); Mirroh (Somalia, Glover \& Gilliland 1185); Marekh (Yemen, Maxwell Darling 170); 'Alat al Jabal (Yemen, Wakefield Expedition 4A).

Variation and taxonomic remarks. Campylanthus junceus is rather uniform throughout its area of distribution, showing some variation in indumentum, leaf length and colour of the corolla. However, this variation is not geographically correlated. One collection, Gillett \& Watson 23672, from Somalia is notable for its exceptionally large leaves and indumentum of very long hairs. However, comparable leaf lengths are found in, for example, Miller \& Long 3488 from northern Yemen and in Thulin, Eriksson, Gifri \& Långström 8047 from Hadramaut in Yemen.

Campylanthus junceus is obviously closely related to C. antonii, which is very similar in vegetative characters. However, the corolla differs both in size (tube to $10 \mathrm{~mm}$ long in $C$. junceus, at least $15 \mathrm{~mm}$ in $C$. antonii), colour (white to pink to blue in $C$. junceus, brownish yellow in $C$. antonii) and in the shape of the lobes (broadly obovate in $C$. junceus, linear in $C$. antonii). It is also related to $C$. pungens, from which it differs in habit $(C$. junceus is a virgate, little-branched shrub, whereas $C$. pungens is a low, much-branched shrub), number of flowers per raceme (usually 10 to more than 15 in $C$. junceus, usually around 5 in $C$. pungens), the longer pedicels (2-4.2mm in C. junceus, $0.8-1.5 \mathrm{~mm}$ in $C$. pungens), the position of the geniculations of the corolla (in middle of tube in C. junceus, in lower third of tube in C. pungens), and in the wider corolla lobes. Furthermore, the geniculations of the corolla tube are much more pronounced in C. junceus than in any other species of Campylanthus.

Selected specimens (from 66 examined). Durbouti. Near turning to Arta, $11^{\circ} 31^{\prime} \mathrm{N}, 42^{\circ} 52^{\prime} \mathrm{E}$, 400m, 10 ii 1994, Thulin 8909 (UPS); Yager, 800m, iv 1957, Chedeville 1164 (FT); Djibouti to Al Sabieh, 14 viii 1960, Giraud s.n. (FT). SomaLIA. Woqooyi Galbeed: Halkulan tug above Anlah pool, Karin near Berbera, 100m, 3 v 1945, Glover \& Gilliland 1185 (BM, K); E of Duwi, $10^{\circ} 01^{\prime} \mathrm{N}, 44^{\circ} 14^{\prime} \mathrm{E}, 1100 \mathrm{~m}, 30$ vi 1981, Gillett \& Watson 23672 (E, K); Foot of Dubriyaad, $10^{\circ} 22^{\prime} \mathrm{N}, 45^{\circ} 10^{\prime} \mathrm{E}, 150 \mathrm{~m}, 3$ i 1933, Gillett 4775 (K). Sanaag: Abdo, Ceelaayo, 3 iv 1945, Glover \& Gilliland 897 (K). Bari: Qandala, 11 ${ }^{\circ} 28^{\prime}$ N , 49 $52^{\prime}$ E, 2 ix 1957, Newbould 1033 (K). Yemen. Hodeida: Northern side of Jabal ar R'as, M'kahl, Wadi Zabid, 600m, 15 x 1976, Wood 1418 (BM); Jabal ar R'as, $14^{\circ} 04^{\prime} \mathrm{N}, 43^{\circ} 36^{\prime} \mathrm{E}, 1300 \mathrm{~m}, 14$ xi 1995, Thulin, Ghebrehiwet \& Gifri 9366 (K, UPS); Jabal ar R'as, 15km NE of Hays, 1450m, 8 iv 1981, Miller \& Long 3488 (E). Dhamar: Sandstone hills just E of Rida, 2100m, 28 iv 1979, Wood 2267 (BM, K). Marib: Between Naqil Hagla and Harib, 5 iii 1980, Wood 3158 (K). Lahij: Coastal plain N of Lahij, in the vicinity of the foothills, 9 x 1962, Popov P32/1 (BM). Aden: Aden, Gold Mohur valley, $12^{\circ} 46^{\prime} \mathrm{N}, 44^{\circ} 59^{\prime} \mathrm{E}, 10-40 \mathrm{~m}, 28$ ix 1992, Thulin, Eriksson, Gifri \& Långström 7847 (K, UPS); Aden, above the tanks and on the terrace to the foot of Jabal Shamsan, 50-200m, 18 iv 1931, Wissmann 1292 (HBG); Aden, slopes towards NE, above Steamer Point, 100m, 16 iv 1931, Wissmann 1305 (HBG). Abyan: Hinterland of Aden, Hadjer Djûel - Aqabet Marma, 31 iii 
1939, Wissmann 2836 (BM); 10km W of Shaqra', 0m, 8 iv 1954, Grierson 137 (E). Hadramaut: Wadi Hajr, Mintaq, 100km W of Al Mukalla, 420m, 13 ii 1989, Miller et al. 8165 (E); Al Mukalla, near College of Education, $14^{\circ} 32^{\prime} \mathrm{N}, 49^{\circ} 08^{\prime} \mathrm{E}, 50-75 \mathrm{~m}, 5$ x 1992, Thulin, Eriksson, Gifri \& Långström 8065 (UPS); $23 \mathrm{~km}$ on the pipeline route starting $15 \mathrm{~km}$ NE of Riyan, $14^{\circ} 50^{\prime} \mathrm{N}, 4^{\circ} 31^{\prime} \mathrm{E}, 200 \mathrm{~m}, 4$ x 1992, Thulin, Eriksson, Gifri \& Långström 8047 (K, UPS).

8. Campylanthus pungens O. Schwartz, Mitt. Inst. Bot. Hamburg 10: 245 (1939). Type: Yemen, Hadramaut [without precise locality], 1931, Wissmann 661 (holo. HBG).

Description. Dwarf shrub to $100 \mathrm{~cm}$ high, usually much lower. Stems subaphyllous, much branched, young branches tinged purple, old ones grey-green, more or less spinescent, glabrous or sometimes scabridulous at base. Leaves linear-subulate, acute, glabrous, $1-5(-7) \times 0.2-0.5(-0.8) \mathrm{mm}$. Flowers usually up to 5 at ends of branches, occasionally up to c. 15 in a $1-4 \mathrm{~cm}$ long raceme; pedicels $0.8-1.5 \mathrm{~mm}$ long, glabrous; bracts $0.9-1.6 \mathrm{~mm}$ long, glabrous to ciliate; bracteoles $0.5-1.2 \mathrm{~mm}$ long, ciliate. Calyx lobes linear to narrowly triangular, acute, $2-5 \times 0.7-1.3 \mathrm{~mm}$, usually ciliate, at least at tips. Corolla hypocrateriform, purple, maroon, mauve, pink or white, glabrous outside; tube $8-10 \times 1-1.5 \mathrm{~mm}$, geniculate in lower third, with retrorse hairs below insertion of stamens inside; lobes ovate, acute at apex, $2.2-3.6 \times 1.2-2.2 \mathrm{~mm}$, glabrous. Anthers $1.8-2.5 \mathrm{~mm}$; filaments $0.3-0.5 \mathrm{~mm}$ long. Ovary slightly compressed, tapering abruptly into style. Style $2-3 \mathrm{~mm}$ long. Capsule round, $4-5.5 \times 3.8-5.2 \mathrm{~mm}$, reddish-brown to dark-reddish brown. Seeds $1.3-1.5 \times 1.3-1.8 \mathrm{~mm}$, light reddishbrown, winged around margin.

Distribution and habitat. Campylanthus pungens is known from Saudi Arabia, Yemen and Oman (Fig. 7) and is thus one of the most widespread species in the genus. However, the distribution is not even throughout its range. There are gaps between the populations around At T'aif and Abha in Saudi Arabia and also between the populations in northern Yemen and those in southeastern Yemen (Hadramaut and Mahrah) and southwestern Oman (Dhofar).

Campylanthus pungens can be found on limestone rocks or slopes, on sandstone hills, in rocky places on granite, on volcanic ground and in sandy loam in wadi flood plains. It usually grows on open ground, but can also be found in open scrub consisting of, for example, Acacia spp., Commiphora spp. and Euphorbia spp. The altitudinal range is from 200 to $2500 \mathrm{~m}$.

Vernacular name. Ghaban (Saudi Arabia, Tothill 75).

Variation and taxonomic remarks. Campylanthus pungens is a uniform species and apart from slight variation in stem indumentum and corolla colour, the only variation worth noting is that some of the collections from Dhofar in Oman are rather tall and have leaves up to $7 \mathrm{~mm}$ long (e.g. McLeish 323) compared with a maximum of $5 \mathrm{~mm}$ in other collections. It appears that this species is heavily grazed in many areas, creating plants with very stunted growth.

The closest relatives of Campylanthus pungens seem to be C. yemenensis and $C$. 
ramosissimus. It is easily distinguished from $C$. yemenensis by its glabrous to papillose vegetative parts (shortly hirsute in $C$. yemenensis) and by the glabrous corolla (shortly hirsute in $C$. yemenensis), and from $C$. ramosissimus by its linear-subulate leaves with acute apices (linear to obovate with obtuse apices in C. ramosissimus), by the longer corolla tube $(8-10 \mathrm{~mm}$ vs. $6-7 \mathrm{~mm})$ and by the position of the geniculations of the corolla tube (lower third in $C$. pungens vs. below the calyx in $C$. ramosissimus). It is also related to $C$. junceus; for distinguishing characters, see under the latter.

Selected specimens (from 39 examined). SAudi Arabia. Makkah: At T'aif road near Hadda', 1680m, sine coll. (K); Alongside At T'aif - Hadda' road, 1650m, 24 ii 1979, Collenette 822 (K); At T'aif, 30 v 1971, Popov 71/155 (BM). Asir: Wadi al Arin, 18 iii 1952, Tothill 75 (BM, HBG); North of Abha, 1km from Bani Rizam, 2200m, 6 v 1982, Podzorski 1188 (E); 70km S of Abha on road to Najran, 2200m, 11 iii 1980, Lavranos \& Collenette 18269 (E). Najran: Base of Qarn Shithath, $17^{\circ} 41^{\prime} \mathrm{N}, 43^{\circ} 30^{\prime} \mathrm{E}, 2100 \mathrm{~m}, 21$ x 1969, Mandaville 2544 (BM). YEMEN. Sadah: 27km W of Sadah, 2200m, 15 xi 1985, FJM 47 (K); Track from Marashi to Al Batan, $16^{\circ} 42^{\prime} \mathrm{N}, 44^{\circ} 16^{\prime} \mathrm{E}, 2160 \mathrm{~m}, 27$ v 1979, Wood \& Heckel Y1246 (E); Sadah to Sanaa road, 20km S of Sadah, 1700m, 23 iii 1981, Miller 3178 (E, K). Sanaa: Naqil Ghaylan, Beni al HarithNehm, 2500m, 31 vii 1980, Wood 3338 (E, K); Sanaa to Ma'rib road, 10km from Sanaa, 2200m, 3 iv 1981, Miller \& Long 3396 (E, K); Huth to Sadah road, 10km N of Al Harf, 1600m, 21 iii 1981, Miller 3157 (E). Dhamar: Hill 79 on W of Dhamar road, $79 \mathrm{~km} \mathrm{~S} \mathrm{of}$ Sanaa, 2500m, 25 vii 1977, Radcliffe-Smith \& Henchie 4761 (K). Hadramaut: Mola Matar area, near Bayn Al-Jibal, $1^{\circ} 47^{\prime} \mathrm{N}, 48^{\circ} 45^{\prime} \mathrm{E}$, 1950m, 6 x 1992, Thulin, Eriksson, Gifri \& Långström 8110 (K, UPS); $50 \mathrm{~km} \mathrm{NW}$ of the coastal road, along the road to Sayun, shortly after Aqabat Abd Allah Gharib, 930m, 20 vi 1987, Boulos et al. 16997 (E, K); Jol, Ras Kureth, 13 iv 1939, Wissmann 3099 (BM). Mahrah: 16km NE of Itab, $15^{\circ} 25^{\prime} \mathrm{N}, 51^{\circ} 32^{\prime} \mathrm{E}$, 400m, 5 xi 1998, Thulin, Beier \& Mohammed A. Hussein 9554 (UPS). Oman. Dhofar: 4.4km on Uyun turnoff, $17^{\circ} 19^{\prime} \mathrm{N}, 53^{\circ} 55^{\prime} \mathrm{E}, 23$ iii 1985, McLeish 505 (E); Mirbat Plain, c. $15 \mathrm{~km}$ E of Mirbat, 200m, 8 ix 1989, Miller \& Nyberg 9202 (E, K); 40km W of Salalah, 2km from Mughsayl, $16^{\circ} 45^{\prime} \mathrm{N}, 53^{\circ} 40^{\prime} \mathrm{E}, 9$ ix 1984, McLeish 323 (E).

9. Campylanthus ramosissimus Wight, Ic. P1. Ind. Or. 4, t.1416 (1849). Type: Pakistan, Limestone range, Hyderabad, 21 iv 1847, Stocks s.n. (holo. K).

Description. Dwarf shrub to $20 \mathrm{~cm}$ high. Stems subaphyllous, much branched, more or less spinescent, papillose. Leaves linear to obovate, obtuse, papillose, $3-7 \times 0.7-2 \mathrm{~mm}$. Flowers up to 5 at ends of branches; pedicels $1.5-3 \mathrm{~mm}$ long, papillose; bracts c. $1 \mathrm{~mm}$ long, papillose; bracteoles $0.5-0.7 \mathrm{~mm}$, papillose. Calyx lobes narrowly triangular, acute, $2-3 \times 1-1.2 \mathrm{~mm}$, papillose, ciliate at least at the tips. Corolla hypocrateriform, colour not known, glabrous outside; tube $6-7 \times 1 \mathrm{~mm}$, geniculate below level of calyx mouth, with retrorse hairs below insertion of stamens inside; lobes narrowly ovate, acute at apex, c. $2.5 \times 1.5 \mathrm{~mm}$. Anthers c. $1.8 \mathrm{~mm}$ long; filaments c. $0.3 \mathrm{~mm}$ long. Ovary ovoid, slightly compressed, tapering abruptly into style. Style $0.8-1.2 \mathrm{~mm}$ long. Capsule somewhat transversely elliptic, $3.5-4 \times 4.2-5 \mathrm{~mm}$, dark brown to blackish. Seeds c. $1 \times 1 \mathrm{~mm}$, light reddish brown, winged around margin.

Distribution and habitat. Campylanthus ramosissimus is apparently restricted to Pakistan, and it is the easternmost representative of the genus (Fig. 6). I have seen 
only the two collections cited, but three additional collections were cited by Stewart (1972: 646). There are no records of habitat or altitudinal range.

Variation and taxonomic remarks. The two collections seen show no notable variation.

In general appearance, Campylanthus ramosissimus is similar to C. pungens; for distinguishing characters see discussion under the latter.

Specimen examined. Pakistan. Hills of Sind, 1849, Stocks 522 (K).

10. Campylanthus mirandae A.G. Mill., Notes Roy. Bot. Gard. Edinburgh 45: 75, fig. 1Aa-h (1988). Type: Oman, Dhofar, Jabal al Qamar, plateau area of western mountains, on southward facing stony steps above seacliffs, x 1984, Morris 258 (holo. E).

Description. Subshrub to $20 \mathrm{~cm}$ high. Stems subaphyllous, much branched, greygreen, more or less spinescent, older stems shortly hirsute, younger branches shortly pilose. Leaves linear-oblong, \pm subulate, acute, shortly hirsute, $3-7 \times 0.5-1 \mathrm{~mm}$. Flowers c. 6 at ends of branches; pedicels c. $2 \mathrm{~mm}$ long, shortly hirsute; bracts linearsubulate, $2-3.5 \mathrm{~mm}$ long, shortly hirsute; bracteoles linear-subulate, $1.5-2 \mathrm{~mm}$ long, shortly hirsute. Calyx lobes linear to narrowly triangular, acute, $3.7-4 \times 0.5-0.6 \mathrm{~mm}$, shortly hirsute on both sides. Corolla hypocrateriform, purple, glabrous outside; tube $7.5-9 \times$ c. $1 \mathrm{~mm}$, lower geniculation below level of calyx, upper geniculation level with mouth of calyx, with retrorse hairs below insertion of stamens inside; lobes broadly obovate, acute at apex, c. $4 \times 2 \mathrm{~mm}$. Anthers c. $2 \mathrm{~mm}$ long; filaments c. $0.4 \mathrm{~mm}$ long. Ovary slightly compressed, tapering abruptly into style. Style $2-2.5 \mathrm{~mm}$ long. Capsule rounded, $3.5-4.5 \times 3.5-4.5 \mathrm{~mm}$, brown. Seeds c. $1 \times 1.1-1.3 \mathrm{~mm}$, light reddish brown, winged around margin.

Distribution and habitat. Campylanthus mirandae is known only from a restricted area of stony terraces in western Dhofar (Fig. 10) at an altitude of c.500m (Miller, pers. comm.). According to Miller (1988), this area is affected by the monsoon and is shrouded in mist between June and September.

Variation and taxonomic remarks. The two specimens seen show no notable variation.

Campylanthus mirandae is likely to be confused only with $C$. pungens among the species occurring in Oman. However, it is easily distinguished by its shortly hirsute vegetative parts (glabrous to papillose in C. pungens). It also resembles $C$. yemenensis from northern Yemen, from which it differs in its longer leaves $(3-7 \mathrm{~mm}$ vs. $0.8-2 \mathrm{~mm}$ ) and the glabrous outside to the corolla (shortly hirsute in C. yemenensis), and $C$. somaliensis, from which it differs in the shorter corolla tube $(7.5-9 \mathrm{~mm}$ vs. $11-14 \mathrm{~mm})$, the shorter style (2-2.5 vs. 5-6mm) and the eglandular indumentum (glandular in C. somaliensis).

Specimen examined. Oman. Dhofar: Jabal al Qamar, x 1984, Morris 561 (E). 
11. Campylanthus yemenensis A.G. Mill., Notes Roy. Bot. Gard. Edinburgh 38: 378, fig. 2d (1980). Type: Yemen, Taizz, slopes of Jabal an Nar [Taizz to Al Mukha road, $25 \mathrm{~km}$ E of Al Mukha], 100m, 21 iv 1977, Lavranos \& Newton 15914 (holo. E).

Description. Dwarf subshrub to $20 \mathrm{~cm}$ high. Stems subaphyllous, much branched, grey-green, more or less spinescent, scabridulous to very shortly hirsute. Leaves linear-subulate, acute, very shortly hirsute, $0.8-2 \times 0.2-0.3 \mathrm{~mm}$. Flowers c. $2-3$ at ends of branches; pedicels $1.5-2.5 \mathrm{~mm}$ long, shortly hirsute; bracts $0.5-1 \mathrm{~mm}$ long, shortly hirsute; bracteoles $0.5-1 \mathrm{~mm}$, shortly hirsute. Calyx lobes linear to narrowly triangular, acute, $2.5-4 \times 0.5-1 \mathrm{~mm}$, shortly hirsute on both sides. Corolla hypocrateriform, mauve, shortly hirsute outside; tube $6-8 \times 1-1.2 \mathrm{~mm}$, lower geniculation below level of calyx, upper geniculation level with calyx mouth, with retrorse hairs below insertion of stamens inside; lobes narrowly ovate, acute at apex, $3.5-4 \times 1.5-1.7 \mathrm{~mm}$. Anthers c. $2 \mathrm{~mm}$ long; filaments c. $0.4 \mathrm{~mm}$ long. Ovary ovoid, slightly compressed, tapering gradually into style. Style $2-2.5 \mathrm{~mm}$ long. Capsule broadly ovoid to round, $3.5-4.5 \times 3-4 \mathrm{~mm}$, brown. Seeds c. $1.5 \times 1.7 \mathrm{~mm}$, light reddish brown, wing restricted to funicular region.

Distribution and habitat. Campylanthus yemenensis is known only from three collections from a rather restricted area east of Al Mukha in Yemen (Fig. 8). The plant represented by Wood 75/225 was found on a rocky bank, otherwise there are no habitat data or records of associated plants. It is found at altitudes between 100 and $300 \mathrm{~m}$.

Variation and taxonomic remarks. The few collections available show no notable variation.

The closest relative of Campylanthus yemenensis is obviously C. pungens, which grows at much higher altitudes in northern Yemen $(1600-2500 \mathrm{~m}$ vs. $100-300 \mathrm{~m})$. However, C. yemenensis is easily distinguished by its shortly hirsute vegetative parts (glabrous to papillose in C. pungens) and by the shortly hirsute outside of the corolla (glabrous in $C$. pungens).

Specimens examined. Yemen. Taizz: On a rocky bank near Al Mafraq between Al Mukha and Taizz, 300m, 26 v 1975, Wood 75/225 (BM, E); Al Bara, on Taizz to Al Mukha road, shortly after Al Mukha turn-off, 300m, 15 iii 1981, Miller 3076 (K).

12. Campylanthus spinosus Balf.f., Proc. Roy. Soc. Edinburgh 12: 84 (1884). Type: Yemen, Socotra, without precise locality, "in campis prope mare abundans", ii-iii 1880, Balfour 101 (lecto., selected here: K).

Syn.: Chamaeacanthus pumilus Chiov., Fl. Somala: 267 (1929). Type: Somalia, Bari, Xaafuun, 23 v 1924, Stefanini \& Paoli 616 (holo. FT, not seen).

Campylanthus spinosus Balf.f. var. kuriensis A.R. Smith, Kew Bull. 25: 189 (1971). Type: Yemen, Abd al Kuri, c.5.7km NE of Jabal Hassala (Qarat Salih), $12^{\circ} 14^{\prime} \mathrm{N}, 52^{\circ} 15^{\prime} \mathrm{E}, 3 \mathrm{~m}$, on a stony slope above a coastal salting, 8 v 1967 , Smith \& Lavranos 706 (holo. K; iso. EA, not seen, FT, not seen, PRE, not seen, W, not seen, WAG). 
Nomenclatural notes. Two syntypes were cited in the protologue of Campylanthus spinosus, Balfour 101 and Schweinfurth 261, both mounted on the same sheet at Kew. Since the name has never been typified, a lectotype needs to be designated. Of the two syntypes Balfour 101 is more complete and in better condition than Schweinfurth 261 and is therefore selected as a lectotype.

Description. Densely branched dwarf shrub to $60 \mathrm{~cm}$ high, but usually much lower; most parts sericeous. Branches distinctly spiny; spines glabrescent, straw-coloured. Leaves linear to elliptic-oblanceolate, fleshy, apex obtuse, $1.5-8 \times 0.5-2 \mathrm{~mm}$. Flowers $2-3$ at ends of branches, below the spine; bracts $1.5-4.5 \times 0.5-1.6 \mathrm{~mm}$; bracteoles $1-3 \times 0.3-1 \mathrm{~mm}$; pedicels $0.5-1 \mathrm{~mm}$ long. Calyx lobes linear to narrowly ovate, $2.5-5 \times 0.5-1.1 \mathrm{~mm}$. Corolla pink to mauve, sometimes almost glabrous outside; tube $6.5-9 \times 1-1.3 \mathrm{~mm}$, geniculate below level of calyx mouth, glabrous below insertion of stamens inside; lobes obovate to broadly obovate, $3-5 \times 2-3 \mathrm{~mm}$, apex acute to obtuse with an irregular margin. Anthers $1-1.5 \mathrm{~mm}$ long; filaments c. $0.3-0.5 \mathrm{~mm}$ long. Ovary slightly compressed, tapering abruptly into style. Style $1-1.5 \mathrm{~mm}$ long. Capsule ovoid to oblong, $3-5 \times 2-3 \mathrm{~mm}$, blackish brown. Seeds $0.6-0.7 \times 0.7-0.9 \mathrm{~mm}$, kidneyshaped; wing restricted to funicular region.

Distribution and habitat. Campylanthus spinosus is found on Socotra (Yemen), the adjacent island of Abd el Kuri and in eastern Somalia (Fig. 10).

Throughout its range Campylanthus spinosus can be found in rocky places on limestone where it grows in low scrub consisting of Acacia spp., Commiphora spp. and Croton spp. It can also be found on sandy or gravelly coastal plains or in gypsum-rich areas. The altitudinal range is between sea level and $1650 \mathrm{~m}$.

Vernacular name. Hamhama (Yemen, Socotra, Miller et al. 8566).

Variation and taxonomic remarks. The protologue of Campylanthus spinosus was rather brief, but a more comprehensive description, accompanied by an excellent illustration, appeared five years later (Balfour, 1888: 203, tab. 61, fig. 1-6).

Campylanthus spinosus is liable to some variation in leaf size, flower size and leaf shape. The variation in leaf shape resulted in the description of C. spinosus var. kuriensis by Smith (1971) from a single collection. This collection (Smith \& Lavranos 706) does indeed have unusually wide leaves, but as intermediate specimens are known from Abd el Kuri (Simony s.n.), Socotra (Thulin \& Gifri 8566) and Somalia (Thulin \& Warfa 5891) I see no reason for retaining C. spinosus var. kuriensis at any rank.

Chiovenda (1929) described Chamaeacanthus pumilus (Acanthaceae) from Somalia, but subsequent research has shown this to be a synonym of Campylanthus spinosus (Miller, 1982).

Campylanthus spinosus is a distinctive species characterized by its dense, shortly sericeous indumentum and spinescent branch tips. It is probably related to $C$. incanus, which has a similar habit and very similar flowers. 
Specimens examined. Somalia. Sanaag: Ceerigaabo, $10^{\circ} 38^{\prime} \mathrm{N}, 47^{\circ} 22^{\prime} \mathrm{E}, 1500 \mathrm{~m}, 7$ ix 1956 , Simmons B50 (EA, K); 1650m, 3 x 1941, Peck 205 (EA, K). Bari: Gees Gwardafuy, $11^{\circ} 50^{\prime} \mathrm{N}$, $51^{\circ} 17^{\prime} \mathrm{E}, 100-150 \mathrm{~m}, 19$ xi 1986, Thulin \& Warfa 5891 (K, UPS); $1 \mathrm{~km}$ E of Qardho town, $9^{\circ} 30^{\prime} \mathrm{N}, 4^{\circ} 05^{\prime} \mathrm{E}, 720 \mathrm{~m}, 26$ iii 1981, Beckett 947 (EA, K); "Bur Hossa Wein”, SE of Dhuudo, 4 iv 1954, Merla, Azzaroli \& Fois s.n. (FT); Sagaleh, near Bandarbeyla, 8 i 1954, Merla, Azzaroli \& Fois s.n. (FT); Nafagallo, near Bandarbeyla, 7 i 1954, Merla, Azzaroli \& Fois s.n. (FT). Nugaal: Laascaanood, 12 x [year unknown; 20th C.], Richards s.n. (K); 95km E of Sinujiif, 40km NW of Eyl airstrip, 1 i 1973, Bally \& Melville 15467 (K); 28km SW of Garoowe on Gaalkacyo road, $8^{\circ} 12^{\prime} \mathrm{N}, 48^{\circ} 16^{\prime} \mathrm{E}, 600 \mathrm{~m}, 5$ v 2001, Thulin, Abdi Dahir, Abdulkadir Khalid \& Ahmed Osman 10439 (UPS). Mudug: 43km S of Hobyo, 60m, 28 xi 1985, Lavranos \& Carter 23477 (EA, K); Without precise locality, Puccioni \& Stefanini s.n. (FT). YemEn. Socotra: R'as Qatanan, $12^{\circ} 21^{\prime} \mathrm{N}, 53^{\circ} 33^{\prime} \mathrm{E}, 20 \mathrm{~m}, 16$ i 1994, Thulin \& Gifri 8566 (K, UPS); 15m, 18 ii 1953, Popov GP/So/135 (EA, BM); Base of R'as Mami on south side, 400m, 2 iii 1989, Miller et al. 8566 (UPS); Below Majah escarpment, Hammaderoh, $12^{\circ} 35^{\prime} \mathrm{N}, 54^{\circ} 17^{\prime} \mathrm{E}, 360 \mathrm{~m}, 6$ iv 1967, Smith \& Lavranos 285 (K); Above path to Qadub, which follows round the base of the N slopes of Jabal Rughid, $12^{\circ} 37^{\prime} \mathrm{N}, 53^{\circ} 58^{\prime} \mathrm{E}, 450 \mathrm{~m}, 13$ iv 1967, Smith \& Lavranos 366 (EA, K, W, WAG); Jabal Rughid, 450m, 4 iv 1953, Popov GP/So/353 (BM); Qallansiya, NE Diorit Peak, 10 iv 1881, Schweinfurth 261 (K); Coast between Qallansiya and Qaysuh, $12^{\circ} 40^{\prime} \mathrm{N}$, $53^{\circ} 29^{\prime} \mathrm{E}$, 0m, 26 iii 1967, Smith \& Lavranos 128 (K); Without precise locality, 1897, Bent s.n. (K); Abd al Kuri, northern slopes of Jabal Eimali, 21 i 1899, Simony s.n. (WU).

13. Campylanthus incanus A.G. Mill., Notes Roy. Bot. Gard. Edinburgh 38: 376, fig. 2i (1980). Type: Somalia, Bari, above Galgalo, 1150m, 28 xi 1972, Lavranos \& Horwood 9038 (holo. E). Fig. 11.

Description. Densely branched dwarf shrub, forming cushions to $30 \mathrm{~cm}$ high, most parts with dense, bifurcate, isotrichous hairs. Young branches somewhat spinescent; older stems glabrescent. Leaves linear, slightly fleshy, with somewhat revolute margins, 3-17 $\times 0.5-1 \mathrm{~mm}$. Flowers $2-3$ at ends of branches; bracts and bracteoles shorter than the pedicels; pedicels $1-2 \mathrm{~mm}$ long, almost glabrous to densely hairy. Calyx lobes narrowly elliptic, $2.5-4.5 \times 0.7-1.5 \mathrm{~mm}$, with acute apices, sparsely hairy, denser at the apices, also with a few very short glandular hairs. Corolla pink to pale lilac to pinkish blue with a yellow centre, $9-14 \mathrm{~mm}$ long, almost glabrous but with a few hairs outside; tube $6-9 \times 0.8-1.1 \mathrm{~mm}$, geniculate below level of calyx mouth, glabrous below insertion of stamens inside; lobes broadly obovate, c.3.2-6 $\times 2.2-5.5 \mathrm{~mm}$. Anthers c. $1.5 \times 0.5 \mathrm{~mm}$; filaments $0.4-0.5 \mathrm{~mm}$ long. Ovary somewhat compressed laterally, abruptly tapering into style. Style 1-2mm long; stigma with papillose surface. Capsule 3.5-4 $\times 2.2-2.8 \mathrm{~mm}$, elliptical, dark brown. Seeds c.0.7mm in diam., rounded, wing restricted to funicular region.

Distribution and habitat. Campylanthus incanus occurs in northeastern Somalia (Fig. 7), where it usually grows on rocky limestone slopes or escarpments with sparse, low shrub vegetation (e.g. Commiphora spp.), but it has also been found on gypsum hills. Apart from the cited material it was also observed and photographed by Mats Thulin at Al Miskaat in the Bari region in January 1997 (Thulin, pers. comm.). The altitudinal range is from 20 to $1550 \mathrm{~m}$. 


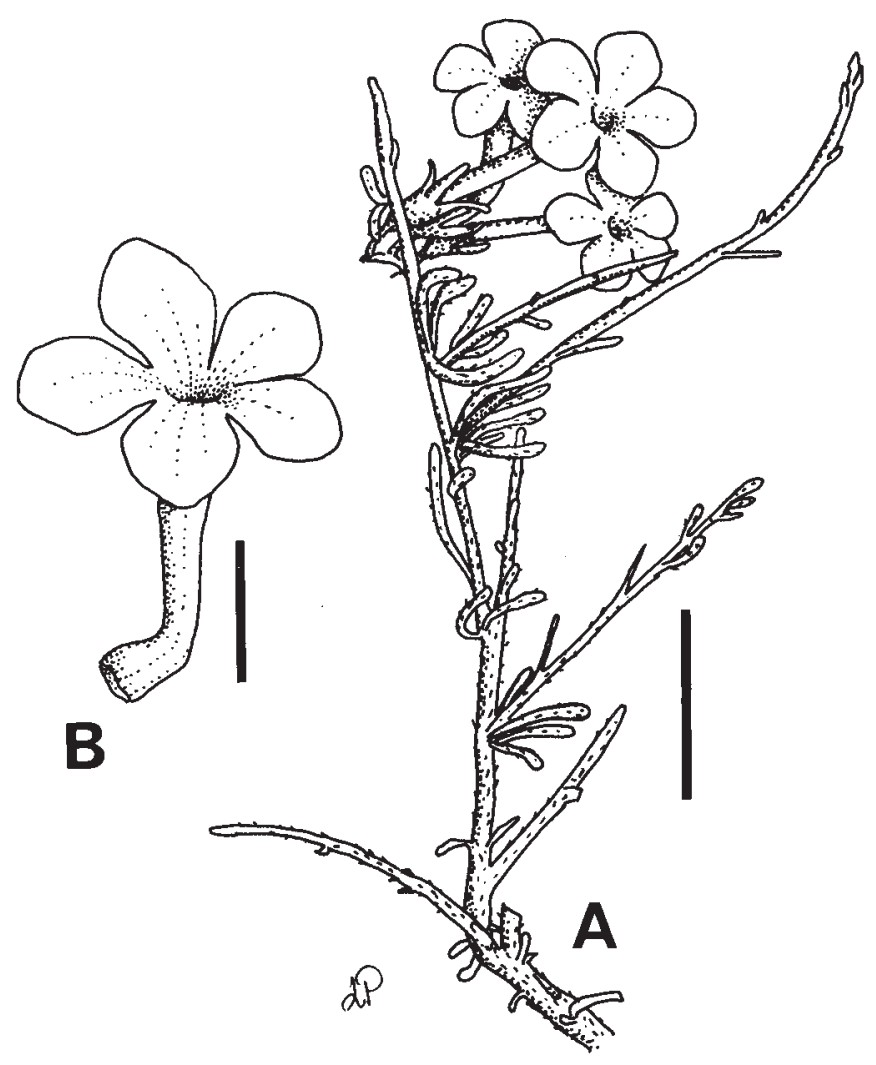

FIG. 11. Campylanthus incanus. A. Habit; bar $=1 \mathrm{~cm}$. B. Corolla; bar $=5 \mathrm{~mm}$.

Variation and taxonomic remarks. Campylanthus incanus is a uniform species, showing some variation in leaf size and flower size only.

Campylanthus incanus is related to C. anisotrichus and C. parviflorus, but is easily distinguished from both these species by the indumentum of bifurcating isotrichous hairs, in contrast to the bifurcating anisotrichous hairs in $C$. anisotrichus and $C$. parviflorus.

Specimens examined. Somalia. Bari: $8 \mathrm{~km} \mathrm{~S}$ of Dhurbo on road towards Ceel Gal, $11^{\circ} 35^{\prime} \mathrm{N}$, 50²1'E, 800m, 22 xi 1986, Thulin \& Warfa 5961 (K, UPS); Ceel Gal, 10 iv 1954, Merla, Azzaroli \& Fois s.n. (FT); Mijertein, $11^{\circ} 35^{\prime} \mathrm{N}, 50^{\circ} 20^{\prime} \mathrm{E}, 450 \mathrm{~m}, 22 \mathrm{v} 1957$, Everard 7 (BM); Bugo Caleed, $11^{\circ} 12^{\prime} \mathrm{N}, 49^{\circ} 55^{\prime} \mathrm{E}, 1200 \mathrm{~m}, 7$ ix 1957, Newbould 1078 (K); Cal Miskaat, 5km S of Dadar, $11^{\circ} 06^{\prime} \mathrm{N}, 49^{\circ} 53^{\prime} \mathrm{E}, 1400 \mathrm{~m}$ s. m., 8 i 2000, Thulin, Abdi Dahir \& Ahmed Osman 10207A (UPS); $30 \mathrm{~km} \mathrm{~S}$ of Bargaal, $11^{\circ} 04^{\prime} \mathrm{N}, 51^{\circ} 03^{\prime} \mathrm{E}, 20 \mathrm{~m}, 24$ xi 1985, Thulin \& Warfa 5511 (K, UPS); $8 \mathrm{~km}$ from Dalweyn along road to Qardho, $10^{\circ} 11^{\prime} \mathrm{N}, 49^{\circ} 01^{\prime} \mathrm{E}, 850 \mathrm{~m}, 22 \mathrm{v} 2001$, Thuli, Abdi Dahir, Abdulkadir Khalid \& Ahmed Osman 10720 (UPS); Above Galgalo, 1150m, 28 xi 1972, Lavranos \& Horwood 9038 (E); $9^{\circ} 21^{\prime} \mathrm{N}, 50^{\circ} 12^{\prime} \mathrm{E}, 370 \mathrm{~m}, 30$ x 1980, Beckett 493 (EA, $\mathrm{K}) ; 114 \mathrm{~km} \mathrm{~N}$ of Garooe on road to Qardho, $5 \mathrm{~km} \mathrm{~S}$ of Dan Gorayo, $8^{\circ} 41^{\prime} \mathrm{N}, 49^{\circ} 18^{\prime} \mathrm{E}, 12 \mathrm{xi}$ 1986, Lavranos \& Carter 24629 (EA, K). 
14. Campylanthus anisotrichus (A.G. Mill.) Hjertson \& A.G. Mill., Edinburgh J. Bot. 57: 224 (2000). Type: Somalia, Woqooyi Galbeed, Maledere, Gowambohale, 24 i 1945, Glover \& Gilliland 616 (holo. EA, not seen; iso. K).

Syn.: Campylanthus incanus var. anisotrichus A.G. Mill. [as "anisotricha"], Notes Roy. Bot. Gard. Edinburgh 40: 331 (1982).

Description. Densely branched dwarf shrub to $30 \mathrm{~cm}$ high. Older branches greyish brown, densely covered with appressed, bifurcate, anisotrichous hairs, with longest arm retrorse, glabrescent below; young branches spinescent, with purplish, glabrescent tips. Leaves linear to very narrowly obovate, fleshy, with somewhat revolute margin, $2-14 \times 0.5-1.5 \mathrm{~mm}$, covered with simple and bifurcate hairs. Flowers c. $2-3$ at ends of branches; bracts and bracteoles shorter than pedicels; pedicels $2-2.5 \mathrm{~mm}$ long, glabrous above, with bifurcate hairs below. Calyx lobes narrowly ovate to narrowly triangular, $3.5-4 \times 0.7-1 \mathrm{~mm}$, almost glabrous with a few very short glandular and simple hairs, particularly along the margins of the lobes, sometimes some bifurcate hairs also present. Corolla purple, $8-11 \mathrm{~mm}$ long, almost glabrous, with a few anisotrichous hairs externally; tube $6-8 \times 1 \mathrm{~mm}$, geniculate below level of calyx mouth, glabrous below insertion of stamens inside; lobes broadly obovate, c. $3 \times 2.5 \mathrm{~mm}$. Stamens inserted c. $3 \mathrm{~mm}$ above the corolla base; filaments c. $0.5 \mathrm{~mm}$ long; anthers c. $1.6 \times 0.6 \mathrm{~mm}$. Ovary tapering abruptly into style. Style c. $0.6 \mathrm{~mm}$ long; stigma with markedly papillose surface. Capsule c. $2.7 \times 2 \mathrm{~mm}$, ovoid, glabrous, dark brownish red. Seeds c. $0.8 \mathrm{~mm}$ in diam., rounded, wing restricted to funicular region.

Distribution and habitat. Campylanthus anisotrichus is known only from three collections from northern Somalia (Fig. 7), where it grows on open, stony ground on limestone at altitudes from 100 to $1500 \mathrm{~m}$. Associated taxa from the $1500 \mathrm{~m}$ locality included Dracaena ombet Kotschy \& Peyr., Tarchonanthus camphoratus L., Monotheca buxifolia (Falc.) A. DC., Buxus hildebrandtii Baill., Dodonaea angustifolia L.f., Euphorbia sp., Aloe sp. and Kalanchoe sp.

Variation and taxonomic remarks. The few collections studied show no notable variation. Campylanthus anisotrichus is closely related to C. parviflorus; for the differences between the two, see under the latter.

Specimens examined. Somalia. Woqooyi Galbeed: Anberoh, near Karin near Berbera, 100m, 2 v 1945, Glover \& Gilliland 1180 (EA, K). Sanaag: $140 \mathrm{~km}$ WSW of Ceerigaabo, $10^{\circ} 24^{\prime} \mathrm{N}$, $46^{\circ} 06^{\prime} \mathrm{E}, 1500 \mathrm{~m}, 27$ xi 1980, Hemming \& Watson 3316 (EA, K).

15. Campylanthus parviflorus Hjertson \& A.G. Mill., Edinburgh J. Bot. 57: 221 (2000). Type: Somalia, Sanaag, $9 \mathrm{~km} \mathrm{~S}$ of Laascaanood, $8^{\circ} 23^{\prime} \mathrm{N}, 47^{\circ} 21^{\prime} \mathrm{E}, 28$ xi 1986, Lavranos \& Carter et al. 24973 (holo. K, iso. EA).

Description. Densely branched, \pm aphyllous shrublet, forming cushions c. $15 \mathrm{~cm}$ high and $30 \mathrm{~cm}$ in diam.; most parts with appressed, bifurcate, anisotrichous hairs with longest arm retrorse. Older branches somewhat gnarled, whitish brown, densely hairy; ultimate branches \pm divaricate, dark brown, $3-10 \mathrm{~mm}$ long, glabrescent, tips 
spinescent, light brown. Leaves linear, fleshy, $1-8 \times 0.3-0.7 \mathrm{~mm}$, sparsely covered with simple and bifurcate hairs, glabrescent. Flowers apparently $2-3$ at ends of branches; bracts and bracteoles shorter than the pedicels; pedicels 1-2mm long, sparsely covered with simple and bifurcate hairs. Calyx lobes narrowly ovate to narrowly triangular, $1.5-2 \times 0.3-0.6 \mathrm{~mm}$, pilose with simple and \pm antrorse bifurcate hairs. Corolla white, c. $4 \mathrm{~mm}$ long, with sparse hairs externally; tube c. $3 \times 1 \mathrm{~mm}$, glabrous below insertion of stamens inside, upper geniculation above calyx mouth; lobes broadly obovate, c. $1.75 \times 1.75 \mathrm{~mm}$. Anthers c. $1.6 \times 0.3 \mathrm{~mm}$; filaments c. $0.3 \mathrm{~mm}$ long. Ovary abruptly tapering into style. Style c. $0.5 \mathrm{~mm}$ long. Capsule c. $2.2 \times 2 \mathrm{~mm}$, ovoid, brownish red. Seeds (immature) c. $0.8 \mathrm{~mm}$ in diam., \pm comma-shaped, wing restricted to funicular region.

Distribution and habitat. Campylanthus parviflorus is known only from the type locality (Fig. 8), where it grows on rocky slopes and gypsum hills with denuded sparse Lannea scrub at an altitude of c. $730 \mathrm{~m}$.

Taxonomic remarks. Campylanthus parviflorus with its small white flowers and divaricate, glabrescent and spinescent branches is a distinctive species. Its closest relative seems to be C. anisotrichus, which grows some $300 \mathrm{~km}$ further to the northwest in Somalia. The latter also has an indumentum of bifurcating, anisotrichous hairs, and branches that are usually somewhat spinescent, albeit not so pronounced as in $C$. parviflorus. However, it differs in the branching pattern, which is not divaricate as in $C$. parviflorus, and in purple flowers that are $8-11 \mathrm{~mm}$ long, as opposed to white and up to about $4 \mathrm{~mm}$ long in C. parviflorus.

\section{ACKNOWLEDGEMENTS}

I wish to thank Dr Mats Thulin for his advice, encouragement and valuable comments on the manuscript. I would also like to thank Prof. Kåre Bremer for his comments on the manuscript, and the directors and curators of the herbaria mentioned under 'Materials and methods', who have kindly provided me with loans or made my visits pleasant and fruitful. Elisabeth Grafström at the Palynological Laboratory, Stockholm, is thanked for her help with the SEM micrographs of pollen. Gary Wife at the Microscopy Unit at the Evolutionary Biology Centre at Uppsala University is thanked for his help with SEM micrographs of stems and seeds. I am also grateful to the staff of our department for technical assistance, and to all my colleagues for their help and support. I am much indebted to Louise Petrusson for the illustration (Fig. 11).

\section{REFERENCES}

Albert, G. (1976). Beiträge zur Morphologie, Anatomie und systematischen Stellung von Campylanthus salsoloides Roth (Scrophulariaceae). Staatsexamensarbeit Mainz (unpublished). 
Argue, C. L. (1993). Pollen morphology in the Selagineae, Manuleae (Scrophulariaceae), and selected Globulariaceae, and its taxonomic significance. Amer. J. Bot. 80: 723-733.

Axelrod, D. I. (1975). Evolution and biogeography of Madrean-Tethyan sclerophyll vegetation. Ann. Missouri Bot. Gard. 62: 280-334.

BALFOUR, I. B. (1884). Diagnoses plantarum novarum phanerogamarum socotrensium, etc. Proc. Roy. Soc. Edinburgh 12: 76-98.

Balfour, I. B. (1888). Botany of Socotra. Trans. Roy. Soc. Edinburgh 31: 1-446.

BALly, P. R. O. (1965). Miscellaneous notes on the flora of tropical East Africa, including descriptions of new taxa. Candollea 20: 13-41.

Bentham, G. (1835). Scrophularineae indicae. London: James Ridgway and Sons.

Bentham, G. (1846). Scrophulariaceae. In: De Candolle, A. (ed.) Prodromus systematis naturalis regni vegetabile, vol. 10, pp. 508, 596. Paris: Victor Masson.

Bentham, G. \& Hooker, J. D. (1886). Genera plantarum, vol. 2, part 2. London: Reeve \& Co.

Bigazzi, M. (1993). A survey on the intranuclear inclusions in the Scrophulariaceae and their systematic significance. Nord. J. Bot. 13: 19-31.

Borgen, L. (1970). Chromosome numbers of Macaronesian flowering plants. Nytt Mag. Bot. 17: 145-161

BramWell, D. (1972). Flora of Macaronesia project. Taxon 21: 730-731.

Bramwell, D. (1976). The endemic flora of the Canary Islands. In: Kunkel, G. (ed.) Biogeography and Ecology in the Canary Islands. The Hague: Dr. W. Junk b.v.

Bramwell, D. \& Murray, B. G. (1972). A preliminary report on the cytology of some Cape Verde Islands plants. Cuad. Bot. Canar. 14-15: 27-29.

BrEMER, K. (1988). The limits of amino acid sequence data in angiosperm phylogenetic reconstruction. Evolution 42: 795-803.

Bremer, K. (1994). Branch support and tree stability. Cladistics 10: 295-304.

Brochmann, C., Rustan, Ø. H., Lobin, W. \& Kilian, N. (1997). The endemic vascular plants of the Cape Verde Islands, W Africa. Sommerfeltia 24: 1-356.

Chevalier, A. (1935). Flore de l'Archipel les Iles du Cape Vert. Rev. Bot. Appl. Agric. Trop. 15: 896-898.

Chiovenda, E. (1929). Flora Somala. Rome: Sindicati Italiano Arti Grafiche.

Cronquist, A. (1978). Once again, what is a species? Beltsville Symp. Agr. Research 2: $3-20$.

DuRietz, G. E. (1930). The fundamental units of biological taxonomy. Svensk Bot. Tidsk. 24: 333-428.

Edgeworth, M. P. (1847). A couple of hours' herborization at Aden. J. Asiat. Soc. Bengal 16: 1217.

Elisens, W. J. (1986). Pollen morphology and systematic relationships among New World species in tribe Antirrhineae (Scrophulariaceae). Amer. J. Bot. 73: 1298-1311.

Endlicher, S. (1839). Scrophulariaceae. In: Endlicher, S. (ed.) Genera Plantarum, pp. 670-696. Wien: Fr. Beck.

Engler, A. (1882). Versuch einer Entwicklungsgeschichte der Pflanzenwelt, vol. 2. Leipzig: Wilhelm Engelmann.

Felsenstein, J. (1985). Confidence limits on phylogenies: an approach using the bootstrap. Evolution 39: 783-791.

Figueiredo, A. (1995). Flora de Cabo Verde, p. 86. Lisbon.

FisCHER, E. (1992). Systematik der afrikanischen Lindernieae (Scrophulariaceae). Tropische und subtropische Pflanzenwelt 81.

Fitch, W. M. (1971). Toward defining the course of evolution: minimal change for a specific tree topology. Syst. Zool. 20: 406-416. 
Ghebrehiwet, M. (2001). Taxonomy, phylogeny and biogeography of Kickxia and Nanorrhinum (Scrophulariaceae). Nord. J. Bot. 20: 655-689.

Gomes, I., Gomes, S., Kilian, N., Leyens, T. \& Lobin, W. (1995). Notes on the flora of the Cape Verde Islands, W Africa. Willdenowia 25: 177-196.

Hallier, H. (1903). Über die Abgrenzung und Verwandtschaft der einzelnen Sippen bei den Scrophularineen. Bull. Herb. Boissier, 2ème Série 3: 181-207.

Hartl, D. (1974). Scrophulariaceae. In: Hegi, G., Flora von Mittel-Europa, vol. 6. 2nd edition. München: Carl Hanser.

Hedge, I. C. \& Miller, A. G. (1977). New and interesting taxa from NE tropical Africa. Notes Roy. Bot. Gard. Edinburgh 35: 179-193.

Hegnauer, R. \& Kooiman, P. (1978). Die systematische Bedeutung von iridoiden Inhaltsstoffen im Rahmen von Wettstein's Tubiflorae. Pl. Med. 33: 1-33.

Hilliard, O. M. (1994). The Manuleae. A Tribe of Scrophulariaceae. Edinburgh: Edinburgh University Press.

Huertson, M. (1996 ['1995']). Taxonomy, phylogeny and biogeography of Lindenbergia (Scrophulariaceae). Bot. J. Linn. Soc. 119: 265-321.

Huertson, M. (1997). Systematics of Lindenbergia and Campylanthus (Scrophulariaceae). Comprehensive Summaries of Uppsala Dissertations from the Faculty of Science and Technology 331.

Huertson, M. \& Miller, A. (2000). A new species and a new combination in Campylanthus. Edinburgh J. Bot. 57: 221.

Holmgren, P. K., Holmgren, N. H. \& Barnett, L. C. (1990). Index Herbariorum. 8th edition. New York: New York Botanical Garden.

Hooker, W. J. (1849). Niger Flora. London: Hippolyte Bailliere.

Kooman, P. (1970). The occurrence of iridoid glycosides in the Scrophulariaceae. Acta Bot. Neerl. 19: 329-340.

LARSEN, K. (1960). Cytological and experimental studies on the flowering plants of the Canary Islands. Biol. Skr. 11: 1-60.

Lebrun, J.-P., Audru, J. \& Cesar, J. (1989). Catalogue des Plantes vasculaires de la Republique de Djibouti. Maisons Alfort: Institut d'Elevage et de Medicine Veterinaire de Pays Tropicaux.

LEMs, K. (1960). Botanical notes on the Canary Islands II. The evolution of plant forms in the Islands: Aeonium. Ecology 41: 261-278.

Licht, W. (1983 ['1982']). Zur Morphogenese der Radikation bei den Veroniceae, III. Campylanthus salsoloides Roth. Beitr. Biol. Pflanzen 57: 291-299.

Lindley, J. (1836). A natural system of botany. London: Longman.

Linnaeus F., C. (1782 ['1781']). Supplementum plantarum. Braunschweig: Impensis orphanotrophei.

LiU, H. Y. (1989). Systematics of Aeonium (Crassulaceae). National Museum of Science, Taiwan, Special Publication 3.

Lobin, W. (1986). Katalog der von den Kapverdischen Inseln beschribenen Taxa höherer Pflanzen (Pteridophyta \& Phanerogamae). Cour. Forsch.-Inst. Senckenberg 81: 93-164.

Mandaville, J. P. (1984). Studies in the flora of Arabia XI: Some historical and geographical aspects of a principal floristic frontier. Notes Roy. Bot. Gard. Edinburgh 42: $1-15$.

Meusel, H. (1953). Über Wuchsformen, Verbreitung und Phylogenie einiger meditteranmitteleuropäischer Angiospermen-Gattungen. Flora 139: 333-393.

Miller, A. G. (1980). A revision of Campylanthus. Notes Roy. Bot. Gard. Edinburgh 38: 373-385.

Miller, A. G. (1982). Further notes on Campylanthus. Notes Roy. Bot. Gard. Edinburgh 40: $331-332$. 
Miller, A. G. (1988). Two new species of Campylanthus. Notes Roy. Bot. Gard. Edinburgh 45: 73-76.

Miller, A. G. \& Morris, M. (1988). Plants of Dhofar, the Southern Region of Oman: traditional, economic and medicinal uses. Oman: Office for Conservation of the Environment.

Miller, A. G. \& Nyberg, J. A. (1991). Patterns of endemism in Arabia. In: Engel, T., Frey, W. \& Kürschner, H. (eds) Flora et Vegetatio Mundi: Contributiones Selectae ad Floram et Vegetationem Orientalis, pp. 263-279. Berlin: J. Cramer.

Minkin, J. P. \& Esbaugh, W. H. (1989). Pollen morphology of the Orobanchaceae and rhinanthoid Scrophulariaceae. Grana 28: 1-18.

Minod, M. (1918). Contribution à l'étude du genre Stemodia et du groupe des Stémodiées en Amérique. Bull. Soc. Bot. Genève 10: 155-252.

Moggi, G. (1963). Note di floristica africana II. Nuove localita africane di "Campylanthus" Roth. Webbia 17: 587-590.

Olmstead, R. G. \& Reeves, P. A. (1995). Evidence for the polyphyly of the Scrophulariaceae based on chloroplast $r b c \mathrm{~L}$ and $n d h \mathrm{~F}$ sequences. Ann. Missouri Bot. Gard. 82: 176-193.

Pitard, J. (1909 ['1908']). In: Pitard, J. \& Proust, L. (eds) Flore de l'Archipel les Iles Canaries. Paris: Paul Klincksieck.

Raven, P. H. \& Axelrod, D. I. (1974). Angiosperm biogeography and past continental movements. Ann. Missouri Bot. Gard. 61: 539-673.

Reichenbach, H. G. L. (1828). Conspectus Regni Vegetabilis per Gradus Naturales Evoluti. Leipzig: Carolum Cnobloch.

Roth, A. W. (1821). Novae Plantarum Species. Halberstadt: H. Vogler.

Sмith, A. R. (1971). Tropical African Plants: 31. Scrophulariaceae. Kew Bull. 25(2): 189.

Stafleu, F. A. \& Cowan, R. S. (1979). Taxonomic literature, vol. 2: H-Le. Regnum Vegetabile 98. Utrecht/Antwerp: Bohn, Scheltema \& Holkema, and The Hague: Dr. W. Junk b.v.

Stewart, R. R. (1972). An annotated catalogue of the vascular plants of West Pakistan and Kashmir. In: Nasir, E. \& Ali, S. I. (eds) Flora of West Pakistan. Karachi: Fakhri Printing Press.

Stuessy, T. F. (1990). Plant Taxonomy. New York: Columbia University Press.

Sunding, P. (1979). Origins of the Macaronesian flora. In: Bramwell, D. (ed.) Plants and Islands, pp. 13-40. London: Academic Press.

Sutton, D. A. (1988). A Revision of the tribe Antirrhineae. London \& Oxford: Oxford University Press.

Sventenius, E. R. (1967). Indices seminum horti acclimat. plantarum arautapensi, vol. 4, p. 47.

Swofford, D. L. (1993). PAUP: Phylogenetic Analysis Using Parsimony, Version 3.1. Computer program. Champaign: Illinois Natural History Survey.

Takhtajan, A. (1986). Floristic Regions of the World. Berkeley: University of California Press.

Thieret, J. W. (1967). Supraspecific classification in the Scrophulariaceae: a review. Sida 3: $87-106$.

Thulin, M. (1985). Revision of Taverniera (Leguminoseae - Papilionoideae). Symb. Bot. Upsal. 25: 45-95.

Thulin, M. (1994). Aspects of distributions and endemism in the arid parts of the Horn of Africa, particularly Somalia. In: Seyani, J. H. \& Chikuni, A. C. (eds)

Proceedings of the XIIIth plenary meeting of AETFAT, Zomba, Malawi, 2-11 April 1991, pp. 1105-1119. Zomba: Monfort Press \& Popular Publications. 
Thulin, M. (1995). A new species of Campylanthus (Scrophulariaceae) from Yemen. Nord. J. Bot. 15: 191-192.

Verdcourt, B. (1958). Notes from the East African Herbarium: VIII. Kew Bull. 13: $218-220$.

Verdcourt, B. (1985). A synopsis of the Moringaceae. Kew Bull. 40: 1-23.

Web в, P. B. (1845). De Campylanthii. Ann. Sci. Nat. Bot. 3: 33-37.

Weв B, P. B. (1848). Campylanthus benthami. In: Hooker, W. J. (ed.) Icon. Pl. tab. 776.

Weв в, P. B. (1849). Spicilegia Gorgonea. In: Hooker, W. J. (ed.) Niger Flora.

London: Hippolyte Bailliere.

Webi, P. B. \& Berthelot, S. (1845). Hist. nat. Iles Canaries, vol. 2: livr. 81, p. 126. Paris.

Wettstein, R. von (1891). Scrophulariaceae. In: Engler, A. (ed.) Die natürlichen Pflanzenfamilien nebst ihren Gattungen und wichtigeren Arten, insbesondere den Nutzpflanzen, pp. 39-107. Leipzig: Wilhelm Engelmann.

White, F. (1983). The Vegetation of Africa. Paris: UNESCO.

White, F. \& LÉonard, J. (1991). Phytogeographical links between Africa and Southwest Asia. In: Engel, T., Frey, W. \& Kürschner, H. (eds) Flora et Vegetatio Mundi: Contributiones Selectae ad Floram et Vegetationem Orientalis, pp. 229-246. Berlin: J. Cramer.

Wickens, G. E. (1982). Studies in the Flora of Arabia: III. A biographical index of plant collectors in the Arabian peninsula (including Socotra). Notes Roy. Bot. Gard. Edinburgh 40: 301-330.

Wight, R. (1849). Icones plantarum Indiae orientalis 4(3). Madras: Messr. Franck and Co.

Zohary, M. (1973). Geobotanical Foundations of the Middle East, vol. 1. Stuttgart: Gustav Fischer Verlag. 